OPEN ACCESS

Edited by:

Karine Rizzoti,

Francis Crick Institute,

United Kingdom

Reviewed by:

Paul Le Tissier,

University of Edinburgh,

United Kingdom

Matan Golan,

Hebrew University of Jerusalem, Israe

*Correspondence:

Suraj Unniappan

suraj.unniappan@usask.ca

Specialty section:

This article was submitted to

Neuroendocrine Science,

a section of the journal

Frontiers in Endocrinology

Received: 07 October 2020

Accepted: 31 December 2020

Published: 23 February 2021

Citation:

Vélez EJ and Unniappan S (2021) A

Comparative Update on the

Neuroendocrine Regulation of Growth

Hormone in Vertebrates.

Front. Endocrinol. 11:614981.

doi: 10.3389/fendo.2020.614981

\section{A Comparative Update on the Neuroendocrine Regulation of Growth Hormone in Vertebrates}

\author{
Emilio J. Vélez and Suraj Unniappan* \\ Laboratory of Integrative Neuroendocrinology, Department of Veterinary Biomedical Sciences, University of Saskatchewan, \\ Saskatoon, SK, Canada
}

Growth hormone $(\mathrm{GH})$, mainly produced from the pituitary somatotrophs is a key endocrine regulator of somatic growth. $\mathrm{GH}$, a pleiotropic hormone, is also involved in regulating vital processes, including nutrition, reproduction, physical activity, neuroprotection, immunity, and osmotic pressure in vertebrates. The dysregulation of the pituitary $\mathrm{GH}$ and hepatic insulin-like growth factors (IGFs) affects many cellular processes associated with growth promotion, including protein synthesis, cell proliferation and metabolism, leading to growth disorders. The metabolic and growth effects of GH have interesting applications in different fields, including the livestock industry and aquaculture. The latest discoveries on new regulators of pituitary $\mathrm{GH}$ synthesis and secretion deserve our attention. These novel regulators include the stimulators adropin, klotho, and the fibroblast growth factors, as well as the inhibitors, nucleobindin-encoded peptides (nesfatin-1 and nesfatin-1-like peptide) and irisin. This review aims for a comparative analysis of our current understanding of the endocrine regulation of $\mathrm{GH}$ from the pituitary of vertebrates. In addition, we will consider useful pharmacological molecules (i.e. stimulators and inhibitors of the GH signaling pathways) that are important in studying $\mathrm{GH}$ and somatotroph biology. The main goal of this review is to provide an overview and update on GH regulators in 2020. While an extensive review of each of the $\mathrm{GH}$ regulators and an in-depth analysis of specifics are beyond its scope, we have compiled information on the main endogenous and pharmacological regulators to facilitate an easy access. Overall, this review aims to serve as a resource on $\mathrm{GH}$ endocrinology for a beginner to intermediate level knowledge seeker on this topic.

Keywords: growth hormone, hormones, pituitary, somatotrophs cells, neuropeptides, vertebrates, cell signaling

\section{INTRODUCTION}

Growth hormone (GH), originally isolated from bovine pituitaries in 1944 (1), is a key endocrine regulator of somatic growth. The main action of pituitary-derived GH is the stimulation of hepatic insulin-like growth factors (IGFs). The GH/IGF axis acts on different target tissues (Figure 1) including the muscle and adipose tissue, to regulate different physiological processes associated with growth promotion, protein synthesis, cell proliferation and metabolism. Therefore, dysregulation of the GH/IGF axis leads to growth disorders. In this regard, alterations in hypothalamic growth 


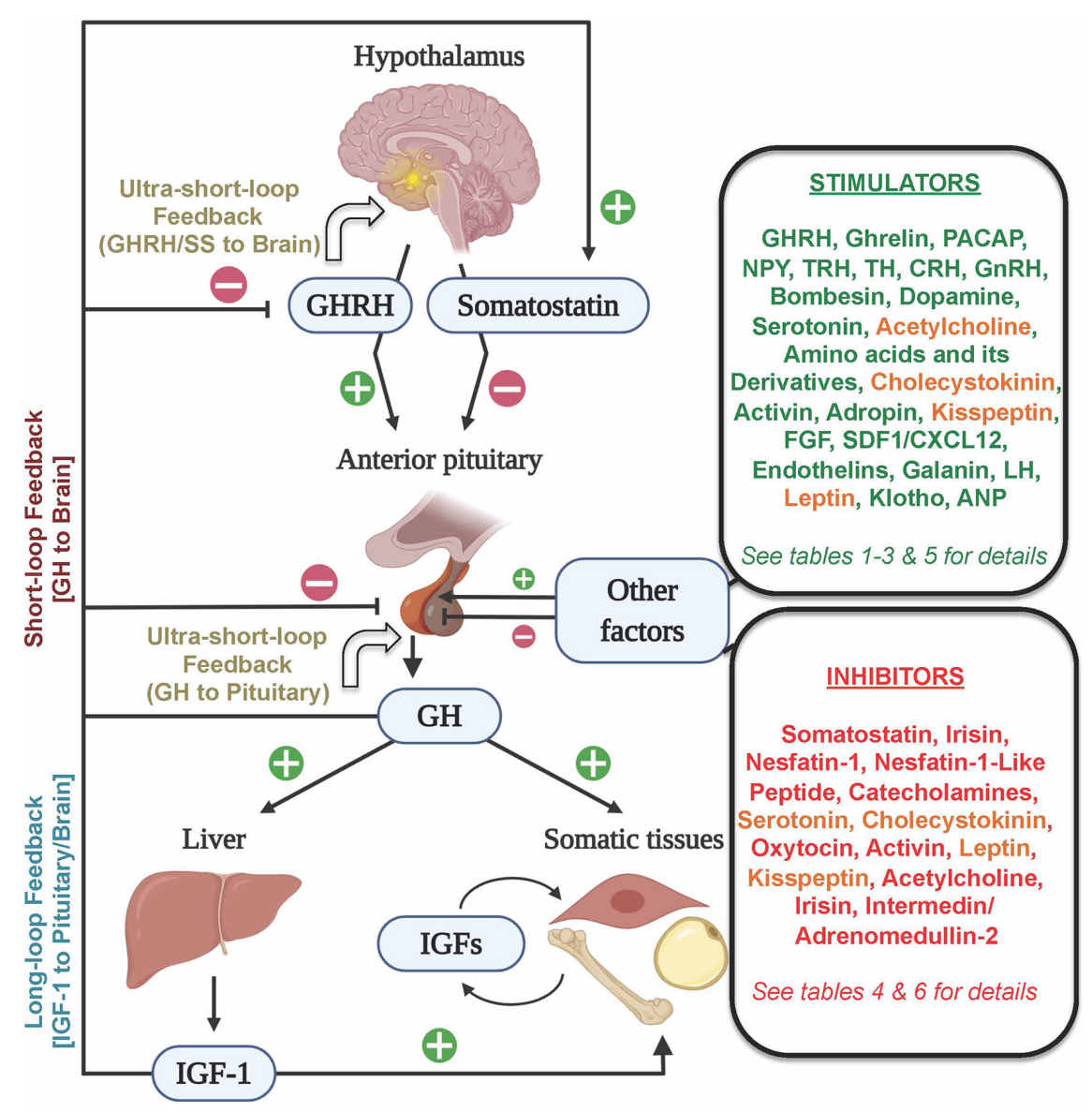

FIGURE 1 | Schematic representation of the neuroendocrine (GHRH/Somatostatin-GH-IGF) axis and its main hormonal regulators. The hypothalamic stimulator $\mathrm{GHRH}$ and the inhibitor somatostatin mainly control GH synthesis and secretion by the pituitary somatotrophs. GH stimulates, mostly in the liver, the secretion of IGF-1, which acts in autocrine, paracrine, and endocrine manners in different somatic tissues to control diverse physiological processes, including protein synthesis, cell proliferation and metabolism. Both GH and IGF-1 could regulate its levels through the long-loop and short-loop feedback mechanisms, while GH and GHRH and somatostatin could regulate their levels via an ultra-short-loop feedback mechanism. Endogenous factors arising outside (shown in two boxes on the right side) of the hypothalamo-pituitary-liver axis could elicit stimulatory (green font), inhibitory (red font) or dual roles (orange font) to regulate pituitary GH. Figure created with BioRender.com tools.

hormone-releasing hormone (GHRH), one of the main stimulators of GH (reviewed in detail below), could affect the pituitary GH and consequently the GH/IGF axis. Moreover, the disorders of the pituitary transcription factors and other components of the GH/IGF axis [GH secretagogues; GHSs, GH- and IGF-receptors, and their signal transducers] also can alter GH production, secretion and responsiveness (2).

The hypersecretion of GH, which is mostly associated with benign pituitary adenomas, causes gigantism or acromegaly (3, 4). Besides, GH excess can increase the risk of developing cancer, cardiovascular diseases, diabetes and osteopathy, and is associated with a reduction in lifespan $(5,6)$. The leading medical therapies for excessive GH consist of the use of somatostatin receptor ligands (SRL), as somatostatin is the main GH inhibitor (reviewed in detail below), and in the limitation of GH actions using antagonists of the GH-receptors $(5,7)$. However, it has been reported that some acromegaly patients become "partially resistant" to SRL treatment (8). In GH deficiency, recombinant and long-acting GH formulations are commonly used as replacement therapies for growth disorders $(6,9)$. Moreover, recombinant human IGF-1 replacement has been useful in reversing the adverse conditions associated with GH deficiency or GH insensitivity in children $(10,11)$. GH treatment was also found useful in treating some catabolic conditions such as AIDS wasting and cystic fibrosis $(2,9,12$, 13). In addition to its clinical relevance as a key molecule of the GH/IGF axis (Figure 1), GH is a pleiotropic hormone involved in several vital processes in vertebrates. These processes include nutrition, metabolism, reproduction, physical activity, neuroprotection, immunity, osmoregulation and even social behavior (14-21). The biological actions of $\mathrm{GH}$ as a major growth and metabolic modulator has been utilized in different fields including the livestock industry (22) and aquaculture (2325). These reinforce the multidisciplinary interest on $\mathrm{GH}$ and the need for progress in GH knowledge across vertebrates. The identification of additional novel regulators of somatotrophs, 
$\mathrm{GH}$ synthesis and secretion has many beneficial outcomes. Some of the relatively recently identified stimulators of pituitary GH secretion or production include adropin, klotho and the fibroblast growth factors, and the inhibitors include irisin and the nucleobindin-encoded peptides nesfatin-1 and nesfatin-1like peptide. The recent advancements in $\mathrm{GH}$ biology, including the regulation of $\mathrm{GH}$ receptors (GHR) and its signal transduction, as well as $\mathrm{GH}$ secretion, have been extensively reviewed in vertebrates including fish $(5,7,14,15,18,21,26-29)$. The goal of this review is to serve as a one-stop resource for readers who seek beginner to intermediate level knowledge on the comparative aspects of GH endocrinology in vertebrates.

\section{GH SYNTHESIS}

$\mathrm{GH}$ is mainly produced and secreted by the somatotrophs of the adenohypophysis (anterior pituitary). Generally, the modulation of these processes begins with the activation of G-protein coupled receptors (GPCRs) in the somatotrophs (Figure 2). The extracellular binding of GHRH to a transmembrane GPCR induces the intracellular linking of a heterotrimeric G protein (composed by $\alpha, \beta$ and $\gamma$ subunits) to the $\operatorname{GPCR}(5,30$, 31). The binding of guanosine triphosphate (GTP) to the $G$ protein induces the dissociation of the $G$ protein and GPCR. That results also in the decoupling of $G \alpha$ and $G \beta \gamma$-subunits (32). In the case of a GH stimulator, the activated $\mathrm{G} \alpha$-subunit $(\mathrm{G} \alpha)$, in turn, stimulates the adenylyl cyclase (AC) activity (33). Accordingly, the subunit involved is recognized as a stimulatory $\mathrm{G} \alpha$ (Gos). Conversely, the binding of a $\mathrm{GH}$ suppressor (somatostatin) activates an inhibitory $\mathrm{G} \alpha$-subunit (Goi), which reduces the activity of $\mathrm{AC}(31,33,34)$. This enzyme catalyzes the conversion of adenosine triphosphate (ATP) into cyclic adenosine monophosphate (cAMP) (35). Once AC is activated, the rise of cAMP levels enables the binding of cAMP to the two regulatory subunits present in the tetrameric protein kinase A (PKA), allowing both the dissociation and activation of the two PKA-catabolic subunits (30). At this point, these activated catabolic subunits can act as serine-threonine kinases to phosphorylate a wide range of substrates, including membrane, cytosolic and nuclear proteins (30, $35,36)$. Within these target substrates, the cAMP-responsive element-binding protein CREB stands out as a critical modulator of the cAMP-PKA-dependent transcriptional regulation in the somatotrophs $(1,31,36)$. The phosphorylation of CREB at Ser133 by PKA allows its binding with the cAMP response element (CRE) (30). CRE acts as a transcription factor of different cAMPregulated genes, including the pituitary-specific positive transcription factor 1 (pit-1), which in turn stimulates the expression of GH gene (Figure 2) (15, 31, 37-39).

On the other hand, it has been reported that activated PKA can limit the levels of cAMP by either the stimulation of phosphodiesterases (PDE) (Figure 2), or through the desensitization of some GPCRs (36, 40-42). Besides, some GH regulators inhibit mRNA encoding their own receptors indicating that hormone desensitization also happens at the transcriptional level in somatotrophs, as observed in rats (43) and in a non-human primate (44). However, no such

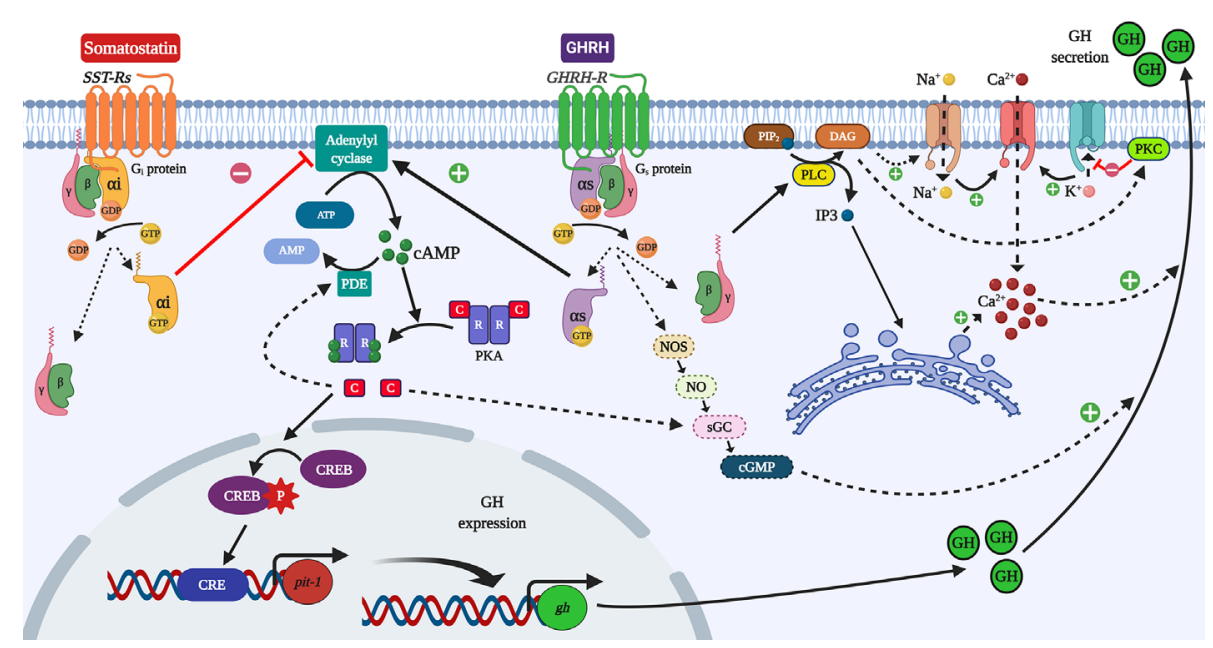

FIGURE 2 | Simplified overview of the cAMP/PKA/CREB pathway in the control of GH synthesis and secretion in somatotrophs. The modulation of GH synthesis starts with the activation of GPCRs and the control of the activity of the adenylyl cyclase (AC) enzyme by the action of either stimulatory G $\alpha$ (Gos) or inhibitory (Goi) subunits. The activation of AC increases CAMP levels, which activates the protein kinase A (PKA). CREB is one of its targets, and phosphorylated CREB can stimulate the expression of the transcription factor pit-1, which upregulates GH mRNAs. The stimulation of phosphodiesterases (PDE) by PKA could elicit a negative feedback, limiting cAMP levels. The activation of adenylyl cyclase and the protein lipase C (PLC) induced by GHRH causes the rise in either cAMP or IP3, respectively, stimulating the calcium $\left(\mathrm{Ca}^{2+}\right)$ influx, which in turn potentiates the exocytosis and release of $\mathrm{GH}$. This mechanism involves the activation of $\mathrm{Na}^{+}$channels to depolarize the plasma membrane to regulate $\mathrm{Ca}^{2+}$ influx by $\mathrm{Ca}^{2+}$-channels, and the mobilization of $\mathrm{Ca}^{2+}$ from the endoplasmic reticulum. It was reported that cGMP could stimulate $\mathrm{GH}$ release independently of cAMP. Otherwise, the limitation of cAMP levels and the activation of $\mathrm{K}^{+}$channels reduce the secretion of $\mathrm{GH}$. Figure created with BioRender.com tools. 
desensitization of a GH-inhibitory GPCR was observed in European eel (45), suggesting species-specific differences in how hypothalamic factors affect somatotrophs in mammals and teleost fish. Sex steroids regulate the fish responsiveness to both $\mathrm{GH}$ stimulators and inhibitors $(14,46,47)$, and it is expected that the responsiveness of fish somatotrophs to hypothalamic factors follows a seasonal pattern associated with the sexual and gonadal maturation typical of each species. The distribution of pituitary endocrine cells in fish and the anatomical configuration of this gland allow the direct innervation from the hypothalamus $(48,49)$. This anatomical feature allows a large number of different neuroendocrine factors to be able to modulate the function of fish somatotrophs $(14,38,50)$. For example, the innervation of the fish pituitary by adrenergic nerve fibers leads to the direct inhibition of $\mathrm{GH}$ secretion by norepinephrine in goldfish pituitary cells $(51,52)$. Meanwhile, in birds and mammals, norepinephrine only causes an indirect, minor effect on GH secretion that is likely dopaminedependent (53). Thus, the regulation of somatotrophs evolved to be less complex during vertebrate evolution [reviewed by Gahete et al. (38)].

\section{GH SECRETION}

The rise in CAMP induced by the activation of $\mathrm{AC}$ modulates the $\mathrm{Ca}^{2+}$ channels to increase calcium influx, thus facilitating the exocytosis and release of GH during its stimulation $(14,35,42$, 50). During GH suppression, the negative regulation of $\mathrm{AC}$ blocks the $\mathrm{Ca}^{2+}$-channels, reducing the release of $\mathrm{GH}(31,33)$. The mechanism behind these is regulated by $\mathrm{Ca}^{2+}$-channels. It lies in the activation of $\mathrm{Na}^{+}$channels to depolarize the plasma membrane, or in the activation of $\mathrm{K}^{+}$channels to hyperpolarize it, which is further regulated by the increase and decrease of cAMP, respectively $(54,55)$. In addition, decoupled G $\beta \gamma$-subunits can modulate the protein lipase C (PLC). The activation of PLC leads to an increase in inositol triphosphate (IP3), stimulating the mobilization of $\mathrm{Ca}^{2+}$ from the endoplasmic reticulum (56) and enhances $\mathrm{GH}$ release. Furthermore, PLC in turn activates protein kinase C (PKC) $(35,44)$, which will also contribute to increased calcium influx by the depolarization of the membrane (Figure 2) $(57,58)$. The PLC/ PKC pathway seems to be the primary intracellular modulator of some of the stimulatory actions of GHSs in mammalian and fish somatotrophs $(35,44,59-62)$. During GH inhibition, in addition to the negative regulation of AC already discussed, the PLC/PKC pathway is also used to block the $\mathrm{Ca}^{2+}$ influx (8).

The stimulation of GH release is also mediated by cyclic GMP (cGMP) in a cAMP-independent mechanism, probably associated with nitric oxide (NO) levels $(14,50,63)$. The NO/ cGMP cascade could be linked to the AC/cAMP/PKA pathway as PKA can phosphorylate the soluble guanylyl cyclase (sGC) (64). Due to this, the NO/cGMP pathway also appears to be involved in the actions of GH inhibitors on somatotrophs (65). Other signaling pathways are involved in mediating the inhibition of GH secretion. Some examples include the phosphatidylinositol 3-kinase/protein kinase B (PI3K/AKT) and the mitogen-activated protein kinase (MAPK) pathways
$(26,55)$. The different mechanisms involving cAMP, PLC/PKC, NO/cGMP, and PKA, contribute to modulate $\mathrm{Ca}^{2+}$ influx and the secretion of $\mathrm{GH}$ in vertebrates including fish. The secretion of $\mathrm{GH}$ in both fish and mammals follows a pulsatile, circadian pattern, with relatively higher release during the dark phase $(7$, $13,14,28,38)$. Besides, sexual dimorphism in GH secretion was observed in rats $(66)$ and humans $(67,68)$, with large nocturnal $\mathrm{GH}$ pulses and low inter-peak levels in males, and a higher interpeak and more sustained secretion in females (38). This differential GH secretion is a key determinant of the genderspecific patterns of growth and metabolism in rodents (69). GH sexual dimorphism was also reported in fish (14). This could be explained, in part, by the sex differences in hormonal regulators of somatotrophs in various species.

\section{MAIN HORMONAL REGULATORS OF SOMATOTROPHS - GHRH AND SOMATOSTATIN}

Two brain (hypothalamus)-derived modulating factors, the stimulator GHRH and the inhibitor somatostatin (70), act as the primary central regulators of both synthesis and secretion of pituitary GH (Figure 1) (1, 7, 14, 15, 20, 21, 26, 34, 38). The hypothalamic GHRH was initially discovered from a human pancreatic tumor associated with acromegaly (71, 72). Later, GHRH was identified in non-mammals, and it was shown that fish GHRH is homologous to mammalian GHRH (73). GHRH is mainly expressed in the brain and testes in numerous vertebrates, including reptiles, birds and mammals (74), as well as in fish (73). Its main receptor is the GHRH-R $(42,75)$. Although it is detected in different tissues in mammals, GHRH-R is mainly expressed in pituitary cells (42). In goldfish, GHRH-R is expressed in the brain and pituitary (73). It was initially thought that GHRH-like peptides do not affect GH secretion in fish (50). Later, it was discovered that those GHRH-like peptides are indeed homologs of the mammalian PACAP (73). In the same article, the real fish homologous to mammalian GHRH was reported, and it was observed that GHRH increased both cAMP and GH secretion in goldfish pituitary cells (73). Similar GH-stimulatory effects of GHRH was identified in amphibians $(76)$, reptiles $(77,78)$, birds and mammals $(42,78,79)$.

Like GHRH, somatostatin is also a hypothalamic peptide, but inhibits GH secretion in vivo and in vitro in rats (80). Different forms of somatostatin, including the mammalian homolog, cortistatin, have been identified in vertebrates $(38,81)$. As reviewed by Sheridan and Hagemeister (26), it is now recognized that various somatostatin forms are expressed in different tissues and it is not restricted to the hypothalamus. Somatostatin exerts its effects in somatotrophs through up to five subtypes of GPCRs, the SST-Rs $(26,34,55)$. The inhibitory actions of somatostatin on $\mathrm{GH}$ release have been widely observed in different fish $(14,26)$. Somatostatin blocks the transcription and translation of $\mathrm{GH}$ in cultured somatotrophs from rainbow trout (82), as well as blunts the stimulatory effects of other factors such as GnRH, dopamine and PACAP (14). GH in fish is under a 
dominant inhibitory control compared to mammals. That means, in the absence of somatostatin, the basal GH secretion reaches the maximum, and the stimulatory factors are ineffective, as observed in the turbot (83). In frogs and turtles, it was thought that somatostatin has no direct effects on somatotroph regulation, but it can block the in vitro stimulatory effects of TRH in amphibians and reptiles (38). Somatostatin strongly inhibits both GH mRNA and secretion from iguana pituitary in vitro, while the same dose and duration failed to modulate $\mathrm{GH}$ in chicken and rat pituitary cultures (78). In mammals, the role of somatostatin is a more complex topic. In male rats, somatostatin appears essential in generating GH secretion rhythmicity, as reviewed by Tannenbaum (84). Considering that somatostatin neurons can directly or indirectly inhibit the activity of GHRH neurons, MacGregor and Leng proposed a mathematical model to explain the hypothalamic control of GH secretion (85). However, results from other mammals, including female rats [Reviewed by Gahete et al. (38)], challenge the role of somatostatin in regulating $\mathrm{GH}$ rhythmicity. More recently, it has been demonstrated that somatostatin irregularly inhibits GHRH neurons in male and female mice, inducing sexspecific oscillatory patterns in the GHRH neural electrical activity (86). The sexual dimorphism in the GHRH oscillatory patterns induced by somatostatin seems dependent on the different actions of both glutamate and GABA neurons, and these differences could explain the distinctive $\mathrm{GH}$ secretion pattern between male and female mice (86). This topic certainly deserves further investigation in the future. In humans, it has been proposed that somatostatin regulates the magnitude of $\mathrm{GH}$ release but is not involved in controlling the rhythmicity of $\mathrm{GH}$ secretion $(38,87)$. In addition to their inhibitory effects, at both low and high doses, somatostatin stimulates the secretion of $\mathrm{GH}$ in primary porcine somatotrophs $(38,81,88)$. On the other hand, SST-Rs can dimerize with other GPCRs such as ghrelin or dopamine receptors, altering the signaling of different factors and consequently, the regulation of GH (61, 89-91). Furthermore, it has been observed that somatostatin can modulate the secretion of GHRH (92), which contributes to this complex regulation. Overall, by eliciting multiple effects detailed above, somatostatin is recognized as the primary inhibitor of $\mathrm{GH}$ in vertebrates $(7,14,15,26,38)$.

In addition to GHRH and somatostatin, there are several additional regulators of GH. For example, gonadal steroids can regulate GHRH effects in mice (69), contributing to the sexually dimorphic secretion of pituitary GH. Indeed, the gonadal steroids secreted during both sexual and gonadal maturation induce a clear seasonal pattern in the $\mathrm{GH}$ plasma levels in aquatic species (14, 93-95). Other factors including IGF-1, GH itself, ghrelin and synthetic GH secretagogs (GHSs) can modulate the synthesis and/ or release of GH by somatotrophs in vertebrates (Figure 1) (5, 7, $15,25,59)$. The levels of IGF-1 in normal situations act as a sensor and feedback regulator of the GH/IGF system. IGF-1, which is mainly expressed in the hepatic tissue, can directly inhibit $\mathrm{GH}$ secretion in the somatotrophs of fish $(18,50,96,97)$, birds $(98,99)$ and mammals $(28,87,92,100)$, through a long-loop negative feedback (by acting on the pituitary and/or on GHRH in the brain,
Figure 1), but also indirectly by enhancing the hypothalamic release of somatostatin (5). In addition, IGF-1 is involved in a wide range of physiological processes including protein synthesis, cell proliferation and differentiation $(17,101)$, and is considered the other major endocrine and local effector of the GH/IGF axis. Besides, GH itself can send feedback signals to the brain (shortloop feedback), or could act in an autocrine or paracrine manner within the pituitary (ultra-short-loop), to limit its synthesis and release by somatotrophs (Figure 1). Both GHRH and somatostatin are also capable of eliciting ultra-short-loop feedbacks within the brain. The exact identification of whether IGF-1 or GH induces the negative feedback in an in vivo model is a complex issue (38), but the inhibitory actions of $\mathrm{GH}$ in mammalian somatotrophs has been demonstrated both in vitro and in vivo (28). Although GH treatment increased GH in grass carp pituitary cells (50), other studies have demonstrated that $\mathrm{GH}$ inhibits GH release in rainbow trout pituitary in vitro (102). A recent in vivo study in gilthead sea bream showed that the administration of a sustained-release formulation of recombinant bovine $\mathrm{GH}$ significantly reduced pituitary $\mathrm{GH}$ mRNA (25). In that research, at 6 weeks post-injection, the reduction of GH mRNA was independent of circulating IGF-1 levels, supporting the negative feedback of GH in this species. To our knowledge, the ultra-short-loop has not been well characterized in the other groups of vertebrates, and future research will undoubtedly help to understand the autoregulation of $\mathrm{GH}$.

As mentioned earlier, the gradual decrease in complexity in the regulation of somatotrophs during vertebrate evolution (38) has led to a large number of factors regulating somatotrophs in fish, while a relatively shorter list of neuroregulators exists in mammals $(14,38)$. However, it is important to note that complexity exists in mammals. Somatostatin neurons can inhibit, directly or indirectly, the activity of GHRH neurons (103). It has been reported that GHS-receptors (GHS-Rs) can dimerize with other GPCRs, including the SST-Rs (61). The heterodimer formation (i.e. GHS-Rs:SST-Rs) could alter the signaling of the GPCRs, and thus its effects, as reported on the regulation of insulin release in rodent pancreatic cells (89). In this sense, chimeric molecules with the ability to bind with both SST-Rs and dopamine receptors induced more potent inhibition of $\mathrm{GH}$ release in human pituitary somatotroph adenoma cells $(90,91)$. Whether this enhanced potency is due to the heterodimerization of the receptors is still unknown. Additional research is needed to fully understand the implication of this mechanism in the regulation of $\mathrm{GH}$ secretion in somatotrophs cells along vertebrates. In addition to the dual regulation of mammalian somatotrophs (i.e. GHRH vs. somatostatin), a wide variety of other factors also modulate the synthesis and secretion of GH in vertebrates. The classical regulators of $\mathrm{GH}$ secretion in amphibians, reptiles, birds, humans and fish were reviewed by different authors in the past $(14,29,38,50)$, and more recently the knowledge on the effects of nutritional status, diet composition and environmental factors on the GH system in fish has been updated $(21,97,104)$. In the present review, while revisiting the classic and main regulators of 
somatotrophs function in vertebrates, our focus is also on new and emerging bioactive molecules and hormones that regulate $\mathrm{GH}$ synthesis and/or secretion. We considered the role of these secondary GH regulators and clustered them as groups of GHstimulatory neurotransmitters (Table 1), neuropeptides (Table 2) and peripheral factors (Table 3), as well as the inhibitory molecules (Table 4). The "up" arrows in these tables indicate a stimulatory effect, while the "down" arrows point to an inhibition. We expand on some of the major regulators below. A very detailed discussion of specifics of each of these factors is beyond the scope of this review. The readers are encouraged to consult several recent reviews of specific topics, and some are cited in this article.

\section{OTHER STIMULATORS OF GH Pituitary Adenylate Cyclase-Activating Polypeptide (PACAP)}

PACAP was originally isolated from the ovine hypothalamus due to its AC-stimulatory effects in rat pituitary cells (167). PACAP presents two molecular forms (PACAP27 and PACAP38) (167, 168) that are expressed in the brain and other peripheral tissues
(169). Initially, it was thought that in fishes and other nonmammals, both GHRH and PACAP were encoded in the same gene, whereas in mammals, they originated from different precursors $(14,170)$. However, later it was reported that in both non-mammals and mammals, PACAP and GHRH are encoded in different genes (169). Regarding receptors, three different subtypes (i.e. PAC1-R, VPAC1-R, and VPAC2-R) have been identified, and they can activate diverse pathways, including the signaling through AC (169). PACAP is a key GHrelease stimulator, which acts through the increase of $\mathrm{Ca}^{2+}$ influx in fish and amphibians (15, 38, 96, 170-172). In this sense, PACAP has been postulated as the GHRH ancestor in less evolved vertebrates $(50,170,173)$. Contrarily, GHRH exerts a stronger stimulation of $\mathrm{GH}$ release than PACAP in chicken somatotrophs (174), and the same occurs in mammals including humans (170). The role of PACAP in the secretion of $\mathrm{GH}$ in mammals is controversial $(38,173)$. It has been observed that while PACAP stimulates GH gene expression in birds, it has no such effects in rodents (78). Therefore, as previously reviewed by Gahete et al. (38), the role of GHRH and PACAP could have evolved during the evolution of

TABLE 1 | Summary of positive regulators of pituitary GH: Neurotransmitters.

\begin{tabular}{|c|c|c|c|}
\hline Neurotransmitters & Groups & Roles & References \\
\hline \multirow[t]{5}{*}{ Dopamine } & Fish & $\uparrow \mathrm{GH}$ mRNA (PKA-dependent) in tilapia & $(105)$ \\
\hline & & $\uparrow \mathrm{GH}$ secretion both directly and somatostatin-dependent in goldfish & $(106,107)$ \\
\hline & & $\uparrow \mathrm{GH}$ secretion in common carp & $(108)$ \\
\hline & Amphibian, reptiles and birds & Little $\uparrow$ or no effect on $\mathrm{GH}$ & $(109,110)$ \\
\hline & Mammals & $\uparrow \mathrm{GH}$ secretion in an isolated case of human acromegaly, but generally $\downarrow \mathrm{GH}$ & (111), Table 4 \\
\hline \multirow[t]{2}{*}{ Serotonin } & Mammals & $\uparrow \mathrm{GH}$ secretion (somatostatin/GHRH-dependent) & $(28,38)$ \\
\hline & Fish and birds & Opposite results also observed & Table 4 \\
\hline \multirow[t]{2}{*}{ Acetylcholine } & Mammals & $\uparrow \mathrm{GH}$ secretion & $(112,113-116)$ \\
\hline & Birds & Opposite results observed in chicken & Table 4 \\
\hline \multirow[t]{4}{*}{ Amino acids and derivatives } & Fish & Glutamate $\uparrow \mathrm{GH}$ secretion in rainbow trout & $(117)$ \\
\hline & & Cysteamine $\uparrow \mathrm{GH}$ secretion through somatostatin-depletion in grass carp & $(118,119)$ \\
\hline & Mammals & Argninine $\uparrow \mathrm{GH}$ mRNA and secretion in rat & $(120,121)$ \\
\hline & & Cysteamine $\uparrow \mathrm{GH}$ secretion through somatostatin-depletion in sheep & $(122)$ \\
\hline
\end{tabular}

TABLE 2 | Summary of positive regulators of pituitary GH: Neuropeptides.

\begin{tabular}{|c|c|c|c|}
\hline Neuropeptides & Groups & Roles & References \\
\hline \multirow[t]{3}{*}{ Cholecystokinin (CCK) } & Fish & $\uparrow \mathrm{GH}$ secretion directly and indirectly (by reducing somatostatin) in goldfish & $(123-125)$ \\
\hline & Mammals & $\uparrow$ in vitro $\mathrm{GH}$ secretion in rat & $(126)$ \\
\hline & & $\downarrow \mathrm{GH}$ in vivo in sheep & Table 4 \\
\hline \multirow[t]{3}{*}{ Activin } & Fish & $\uparrow \mathrm{GH}$ release in perifused pituitary fragments of goldfish & $(127)$ \\
\hline & & $\downarrow$ GH mRNA in zebrafish & Table 4 \\
\hline & Mammals & $\uparrow \mathrm{GH}$ mRNA and secretion in rat, with exceptions & (128), Table 4 \\
\hline Adropin & Fish & $\uparrow \mathrm{GH}$ mRNA in pituitary cells of tilapia & $(129)$ \\
\hline \multirow[t]{3}{*}{ Kisspeptin } & Fish & $\uparrow \mathrm{GH}$ secretion in pituitary cells from goldfish & $(130,131)$ \\
\hline & Mammals & $\uparrow \mathrm{GH}$ secretion in peripubertal rats & $(132)$ \\
\hline & & $\uparrow$ GH secretion in fasted sheep (ghrelin-NPY dependent), but could also $\downarrow$ it & (133), Table 4 \\
\hline Fibroblast Growth Factor (FGFs) & Mammals & $\uparrow \mathrm{GH}$ secretion in rat pituitaries and human adenoma cultures & $(134)$ \\
\hline Chemokine derived factor 1 (SDF1, aka CXCL12) & Mammals & $\uparrow \mathrm{GH}$ mRNA and secretion in rat & $(135,136)$ \\
\hline Endothelins & Mammals & $\uparrow \mathrm{GH}$ secretion - ghrelin dependent- in bovine & $(137,138)$ \\
\hline \multirow[t]{3}{*}{ Galanin } & Fish & $\uparrow \mathrm{GH}$ release in vivo or in vitro in coho salmon and goldfish & (139) \\
\hline & Birds & $\uparrow \mathrm{GH}$ secretion acting directly on the pituitary & $(140)$ \\
\hline & Mammals & $\uparrow \mathrm{GH}$ release directly and indirectly & $(141-145)$ \\
\hline LH & Fish & Essential for $\mathrm{GH}$ synthesis and release in grass carp & $(50,146)$ \\
\hline
\end{tabular}


TABLE 3 | Summary of positive regulators of pituitary GH: Peripheral factors/other factors.

\begin{tabular}{|c|c|c|c|}
\hline Neuropeptides & Groups & Roles & References \\
\hline \multirow[t]{6}{*}{ Leptin } & Fish & $\downarrow \mathrm{GH}$ mRNA & Table 4 \\
\hline & Mammals & $\uparrow \mathrm{GH}$ secretion directly and indirectly (i.e. somatostatin) in pig perifused pituitaries & $(147,148)$ \\
\hline & & $\uparrow \mathrm{GH}$ secretion in sheep & $(149)$ \\
\hline & & $\uparrow \mathrm{GH}$ secretion in anterior pituitary explants of fasted bovids & $(150)$ \\
\hline & & The lack of leptin receptor $\downarrow$ both GH mRNA and protein in mice & $(151)$ \\
\hline & & Administration $\uparrow$ increases pituitary GH content in leptin-deficient obese mice model & $(152)$ \\
\hline Klotho & Mammals & $\uparrow \mathrm{GH}$ secretion in vitro and in vitro in rodents, and in human $\mathrm{GH}-$ secreting adenomas & $(134)$ \\
\hline Atrial and ventricular natriuretic peptides & Fish & $\uparrow \mathrm{GH}$ release in tilapia cultured pituitaries & (153) \\
\hline
\end{tabular}

TABLE 4 | Summary of negative regulators of pituitary GH.

\begin{tabular}{|c|c|c|c|}
\hline Molecules & Groups & Roles & References \\
\hline \multirow{4}{*}{$\begin{array}{l}\text { Catecholamines [norepinephrine (NE), } \\
\text { epinephrine and dopamine] }\end{array}$} & Fish & NE and epinephrine $\downarrow$ basal GH release from pituitary cells of goldfish & $(106)$ \\
\hline & Birds & $\mathrm{NE} \downarrow \mathrm{GHRH}$-effects in chicken pituitary & $(110)$ \\
\hline & Mammals & $\mathrm{NE} \downarrow$ basal and GHRH-stimulated GH release in cultured ovine pituitary cells & $(154)$ \\
\hline & & $\begin{array}{l}\text { Dopamine } \downarrow \text { GH mRNA and secretion in sheep, cattle and human neonates, but } \\
\text { opposite role also observed }\end{array}$ & $\begin{array}{l}(143,155,156), \\
\text { Table } \mathbf{1}\end{array}$ \\
\hline \multirow[t]{3}{*}{ Serotonin } & Fish & $\downarrow \mathrm{GH}$ in vitro secretion in goldfish & $(157)$ \\
\hline & Birds & $\downarrow$ GH secretion -hypothalamus-dependent- in chicken & $(158)$ \\
\hline & Mammals & Opposite role observed & Table 1 \\
\hline \multirow[t]{2}{*}{ CCK } & Mammals & $\downarrow$ GH in sheep, but opposite role observed in rat & (159), Table 2 \\
\hline & Fish & Opposite role observed in goldfish & Table 2 \\
\hline Oxytocin & Mammals & $\downarrow \mathrm{GH}$ secretion in rat & $(160)$ \\
\hline \multirow[t]{3}{*}{ Activin } & Fish & $\downarrow$ GH expression in cultured pituitaries of zebrafish & $(96)$ \\
\hline & & Opposite role observed in goldfish & Table 2 \\
\hline & Mammals & $\downarrow \mathrm{GH}$ mRNA in rat, but opposite role also observed & (161), Table 2 \\
\hline \multirow[t]{2}{*}{ Leptin } & Fish & $\downarrow \mathrm{GH}$ mRNA in tilapia & $(162)$ \\
\hline & Mammals & Opposite role observed & Table 3 \\
\hline \multirow[t]{2}{*}{ Kisspeptin } & Mammals & $\begin{array}{l}\text { Endogenous kisspeptin can } \downarrow \text { GH secretion through GPR54 in sheep, but } \\
\text { opposite role also observed }\end{array}$ & $(163)$ \\
\hline & Fish & Opposite role observed in goldfish & Table 2 \\
\hline Irisin & Fish & $\downarrow \mathrm{GH}$ mRNA and secretion in tilapia in vitro & $(164)$ \\
\hline Intermedin/Adrenomedullin-2 & Mammals & $\downarrow \mathrm{GHRH}-$ stimulated $\mathrm{GH}$ release in rat dispersed pituitary cells & $(165)$ \\
\hline \multirow[t]{2}{*}{ Acetylcholine } & Birds & $\downarrow$ GH secretion -hypothalamus-dependent- in chicken & (168) \\
\hline & Mammals & Opposite effect observed & Table 1 \\
\hline Nesfatin-1 and NLP & Mammals & $\downarrow \mathrm{GH}$ mRNA and protein in rat pituitary cells & $(166)$ \\
\hline
\end{tabular}

vertebrates. While both GHRH and PACAP exert equipotent action regulating $\mathrm{GH}$ in amphibians and reptiles, in birds and mammals, PACAP only plays a secondary role, with GHRH being the main GH stimulator in those groups (170).

\section{Neuropeptide Y (NPY)}

NPY was first isolated from the pig brain (175) and is a member of a family of peptides that includes three (i.e. peptide Y, peptide YY, and the pancreatic polypeptide) additional GPCR agonists (176-178). NPY was identified later in different fish species (179, 180). In mammals NPY has been located in the brain (176), although NPY immunoreactivity was detected in several tissues in vertebrates, including the fish pituitary $(179,180)$. NPY is recognized as one of the most important regulators of energy homeostasis and food intake in both fish and mammals (178, 180). Besides, NPY acts on fish somatotrophs to increase GH secretion both in vitro and in vivo (181-183). To our knowledge, there are no published reports on the involvement of NPY on GH regulation in birds, reptiles and amphibians. The role of NPY in mammals is controversial, and appears speciesspecific: stimulates GH secretion in swine (184) and cows (185), in rodents NPY reduced GH (186), increased it (187), or had no effects on the secretion of GH (188). A more recent work reported that NPY stimulates the secretion of GH through its action at the hypothalamic level by the control of GHRH and somatostatin in sheep (133). Additional work is necessary to clarify whether NPY exerts a direct action on mammalian somatotrophs.

\section{Thyrotropin-Releasing Hormone (TRH)}

TRH, the first hypothalamic hypophysiotropic factor characterized, was initially isolated from the porcine and ovine hypothalamus in $1969(189,190)$. TRH is mainly expressed in the hypothalamus of fish, amphibians, birds and mammals, and has been detected in a number of peripheral tissues in reptiles (74). TRH binding was initially observed in the plasma membrane of the anterior pituitary extracted from cattle (191), and the receptor was later identified as a GPCR in mice (192). Although the main role of TRH is the 
stimulation of the synthesis and release of the thyroid stimulating hormone (TSH) to control the thyroid gland (192), TRH influences the secretion of other pituitary hormones (38). In fact, TRH increases GH expression or secretion in some fish species (14, $50)$, amphibians (193), reptiles $(78)$, birds $(78,194)$ and mammals $(78,195)$. In chickens, TRH stimulates GH with a potency similar to that of GHRH (99). On the other hand, TRH could also indirectly stimulate $\mathrm{GH}$ through thyroid hormones (see below).

\section{Thyroid Hormones (THs)}

THs exist in two forms, the predominant circulating T4, and the biologically active T3 (196), which are essential components of the pituitary-thyroid axis (192). In mammals, it is well known that TRH induces the synthesis of TSH by the pituitary, which in turn induces the synthesis and release of T4 by the thyroid gland. Then, T4 can be enzymatically converted by deiodinases to T3 in different tissues, including the brain and liver $(192,196)$. THs can regulate the transcription of different target genes, mainly through their interaction with nuclear receptors (TRs) $(196,197)$. THs can also modulate gene expression through non-genomic actions involving the activation of different signaling pathways $(196,198)$. In fish, TRs have been found in the pituitary $(50)$, and little evidence exists on the non-genomic actions of THs in these species [recently reviewed by Deal and Volkoff (196)]. The transcriptional regulation induced by the THs contributes to the modulation of various physiological processes, including development, growth and metabolism. In fact, THs stimulate the synthesis and release of pituitary GH in some fish $(199,200)$ and rats (201-204), though contrary or no effects have been observed in other fish species, reptiles or birds $(15,196)$. Not much is known about the TH regulation of GH in reptiles and amphibians (205), and the discrepancies in $\mathrm{TH}$ effects on $\mathrm{GH}$ regulation among fish have been recently summarized by Deal and Volkoff (196).

To our knowledge, the reasons behind the inconsistencies in the regulation of $\mathrm{GH}$ by $\mathrm{THs}$ are not fully understood. A combination of two different factors could have contributed to these contradictory results. As previously discussed by Giustina and Wehrenberg (206), the maintenance of basal GH secretion, to some extent, depends on the stimulation of somatotrophs by THs. Otherwise, when the concentration of THs exceeds the physiological level, it can increase the secretion of somatostatin and decrease GHRH, eventually causing a downregulation of pituitary GH (206). On the other hand, it has been reported that THs can stimulate the synthesis and release of hepatic IGF-1 in both fish and mammals (207-209), which through the long-loop negative feedback (Figure 1) could elicit a suppression of pituitary GH secretion. Based on these, the different effects of $\mathrm{TH}$ on $\mathrm{GH}$ observed in various species are likely caused by the high doses of THs used in those studies (i.e. excess vs. physiological levels), or by its effects on hepatic IGF-1. This aspect requires future confirmation through additional research.

\section{Corticotropin-Releasing Hormone (CRH)}

$\mathrm{CRH}$, also known as corticotropin releasing factor (CRF), was first identified in ovine hypothalamus (210) and later in other vertebrates, including fish and amphibians (211). Although recognized as a hypothalamic hormone, $\mathrm{CRH}$ was located in other human tissues $(212,213)$. CRH exerts its actions through GPCRs (214). In the pituitary, CRH stimulates the secretion of adrenocorticotropic hormone (ACTH) $(180,213)$ and can induce the release of other pituitary hormones such as $\alpha$ melanocyte-stimulating hormone $(\alpha-\mathrm{MSH})$ and $\beta$-endorphin (215). Similarly, CRH is recognized as a GH-release stimulator in non-mammals (38). While CRH stimulates $\mathrm{GH}$ in reptiles (77) and in European eel, but had no effects in turbot (83). CRH is a potent stimulator of TSH release from the pituitary of amphibians, fish and birds [reviewed by De Groef (216)]. Some of the $\mathrm{CRH}$ effects could be attributed to its indirect action via thyroid hormone stimulation. Although $\mathrm{CRH}$ was not considered a stimulator of GH in mammals (217), a paradoxical increase of $\mathrm{GH}$ in response to $\mathrm{CRH}$ was observed in patients with pituitary adenomas (38) and this is a topic under consideration in current research $(218,219)$.

\section{Gonadotropin-Releasing Hormone (GnRH)}

GnRH was first isolated in the early 1970s from the porcine hypothalamus (220). As recently reviewed by Duan and Allard (221), GnRH has been identified in a wide range of vertebrates, including fish, amphibians, reptiles, birds and mammals. This hypothalamic factor exerts its action in the pituitary cells through the activation of GPCRs and the signaling by PLC and cAMP pathways $(222,223)$. As a result, $\mathrm{GnRH}$ regulates the secretion of FSH and LH and is recognized as a critical modulator of the reproductive axis (224). Goldfish somatotrophs express $\mathrm{GnRH}$ receptors $(225,226)$. GnRH stimulates the secretion of $\mathrm{GH}$ in goldfish (227-229), tilapia (105) and Ricefield eel (230), but not in some others as found in African catfish or rainbow trout (231, 232). However, it was observed in pituitary cell culture of rainbow trout, GnRH stimulates GH secretion only in the presence of IGF1 (233). GnRH could indirectly stimulate somatotroph function through the paracrine action of $\mathrm{LH}$, which can also act as a stimulator of $\mathrm{GH}$ as reported in grass carp $(50,146)$ (Table 2). The regulation of $\mathrm{GH}$ by $\mathrm{GnRH}$ is a species-specific response depending on the presence of IGF-1 or other factors such as $\mathrm{LH}$, or the type of receptor involved. Although it was postulated that the $\mathrm{GH}$ secretagogue actions of $\mathrm{GnRH}$ could be restricted to fish (38), recently it was found that $\mathrm{GnRH}$ stimulates $\mathrm{GH}$ secretion in the iguana, and both GH mRNA and GH secretion in chickens (78). Besides, GnRH combined with enkephalin increased $\mathrm{GH}$ secretion in rat pituitary cells (234), and long-term treatment with $\mathrm{GnRH}$ in humans caused an increase in height in precocious puberty (235).

\section{Bombesin (BB)}

Bombesin was first isolated from the skin of frogs in 1970 (236). $\mathrm{BB}$ immunoreactivity was found in reptiles (237), and two homologs, GRP and neuromedin B, were found in birds and mammals $(238,239)$. BB expression was also found in different fish species $(240,241)$, as is the case of the forebrain and pituitary of goldfish (241). Among other functions, BB stimulates the secretion of gastric acid and pancreatic enzymes (238) and is involved in the modulation of the stress response (239). As an 
activator of GPCRs (242), it has been reported that BB stimulates $\mathrm{GH}$ secretion in rat both in vivo (243) and in vitro (244). Contrarily, other authors found that $\mathrm{BB}$ reduced $\mathrm{GH}$ secretion in rats by the stimulation of somatostatin release (245). This controversial response could be associated with the presence of estrogens, as it was reported that bombesin inhibits $\mathrm{GH}$ secretion in normal rats but exerts stimulatory role in estrogenized rats (246). In contrast, BB stimulated GH secretion in cultured bovine pituitary cells (112). In goldfish, the perifusion of pituitary with BB significantly increased GH secretion (241). In the same species, $\mathrm{BB}$ increased $\mathrm{GH}$ release and inhibits the expression of somatostatin $(123,124)$, and it has been postulated that the actions of $\mathrm{BB}$ in the regulation of $\mathrm{GH}$ in these species could be mediated by somatostatin (14). However, whether $\mathrm{BB}$ can regulate $\mathrm{GH}$ synthesis and secretion in other fish, amphibians, reptiles and birds is unknown.

\section{Ghrelin}

Ghrelin was originally reported in 1999 (247), as the first and only known endogenous ligand of the growth hormone secretagogue receptor 1a (GHS-R1a) (248). It was purified from the stomach extracts of rats, and was later identified in a number of species from humans to invertebrates. The Nterminal region of ghrelin is very highly conserved across species, and in most species, the third serine has an octanoyl group (249). This highly conserved region with the acyl group is considered to be the bioactive core of ghrelin, and it is critical for ghrelin binding to its receptor (249). GHS-R1a, currently known as the ghrelin receptor, is expressed in the pituitary somatotrophs and allows the direct action of ghrelin on these cells to induce GH synthesis and secretion. Ghrelin is known to stimulate GH secretion in many species including rats $(250,251)$, humans $(252$, 253), birds $(103,254)$, and fish (255-260). These effects are either in vitro, supporting the ability of ghrelin to act directly on somatotropes, or in vivo, by acting directly or through influencing the multitude of other $\mathrm{GH}$ regulators $(14,50)$. The binding of acylated ghrelin to its receptor triggers a cascade of intracellular events, including the stimulation of phospholipase C, inositol triphosphate and calcium pathways (261, 262). Overall, almost two decades since its discovery, ghrelin is now considered as one of the most important hormonal regulators of $\mathrm{GH}$ in vertebrates.

\section{Other Stimulators}

In this review, we have tabulated the neurotransmitters (Table 1), neuropeptides (Table 2) and the peripheral factors (Table 3). Their specific effects in different species or groups are also furnished in these tables. In addition to the factors already discussed, a wide variety of other minor factors have been shown to exert a GH stimulatory role. For example, it has been recently reported that the peptide hormone adropin, which participates in the regulation of vascular function and energy homeostasis in mammals, stimulates $\mathrm{GH}$ gene expression in the pituitary of tilapia (129). To our knowledge, it is unknown whether adropin participates in the regulation of GH secretion in other groups of vertebrates. On the other hand, it has been observed that the transmembranal protein klotho, originally recognized as an ageing-suppressor in mice, increases $\mathrm{GH}$ secretion both in vitro and in vitro in rodents, as well as in human GH-secreting adenomas (134). Moreover, klotho is a modulator of the IGF-1 signaling pathway. It can inhibit the peripheral actions of IGF-1, and block the negative feedback of IGF-1 on pituitary GH secretion (92). Consequently, klotho has been postulated as a new player in the regulation of GH/IGF axis in mammals (92). However, the potential role of klotho in the regulation of $\mathrm{GH}$ secretion in other groups of vertebrates, including fish, is unknown. Besides, klotho can also regulate the signaling pathway of the fibroblast growth factor (FGF) (134). The same authors have also observed that FGF increased GH secretion in both rat pituitaries and human adenoma cultures (134). While it is unknown whether FGF exerts a direct action on GH regulation in other vertebrates, it has been recently observed that FGF increases the secretion of ghrelin in zebrafish (263). Thus, it is expected that FGF could also influence (at least indirectly) GH levels in fish. Certain amino acids, including aspartic acid, glutamic acid and arginine, although recognized as classical regulators of $\mathrm{GH}$, was thought not to act directly on somatotrophs (264-266). However, new in vitro studies have shown that some amino acids exert their effects directly at the pituitary level (Table 1). However, it is important to note that some molecules may have species-specific roles and exert inhibitory actions, as detailed in Table 4. In addition to the endocrine regulators of $\mathrm{GH}$ discussed here, a large number of pharmacological compounds were employed to study the regulation of $\mathrm{GH}$ in somatotrophs. We have summarized the main pharmacological stimulators (Table 5) of the major signaling pathways involved in the regulation of both the synthesis and secretion (Figure 2) of GH. For further details on the use of these molecules, and the most effective doses or concentration ranges reported, please refer to the literature cited in the table.

\section{OTHER GH INHIBITORS}

Other factors with an inhibitory role on GH are summarized in Table 4. Note that some molecules may have species-specific roles and exert the opposing actions, as detailed in Tables 1-3. For example, it has been reported that irisin, which is recognized as a metabolic peptide in mammals, inhibits both GH mRNA and secretion in cultured pituitary cells of tilapia (164). It is unknown whether irisin has a direct modulatory role on $\mathrm{GH}$ synthesis and secretion in other vertebrates. An inverse association between GH and irisin levels has been observed in humans, as the administration of recombinant human GH in young patients with Turner syndrome increased the circulating levels of irisin (281). We have reported that two novel metabolic peptides, nesfatin-1 and nesfatin-1-like peptide, are negative modulators of the synthesis of pituitary GH in mammals (166). Although their receptors are still unknown, it is expected that these peptides act through GPCR (282). It has been shown that both nesfatin-1 and nesfatin-1-like peptide regulate $\mathrm{GH}$ in the 
TABLE 5 | Selection of GH signaling pathway stimulators.

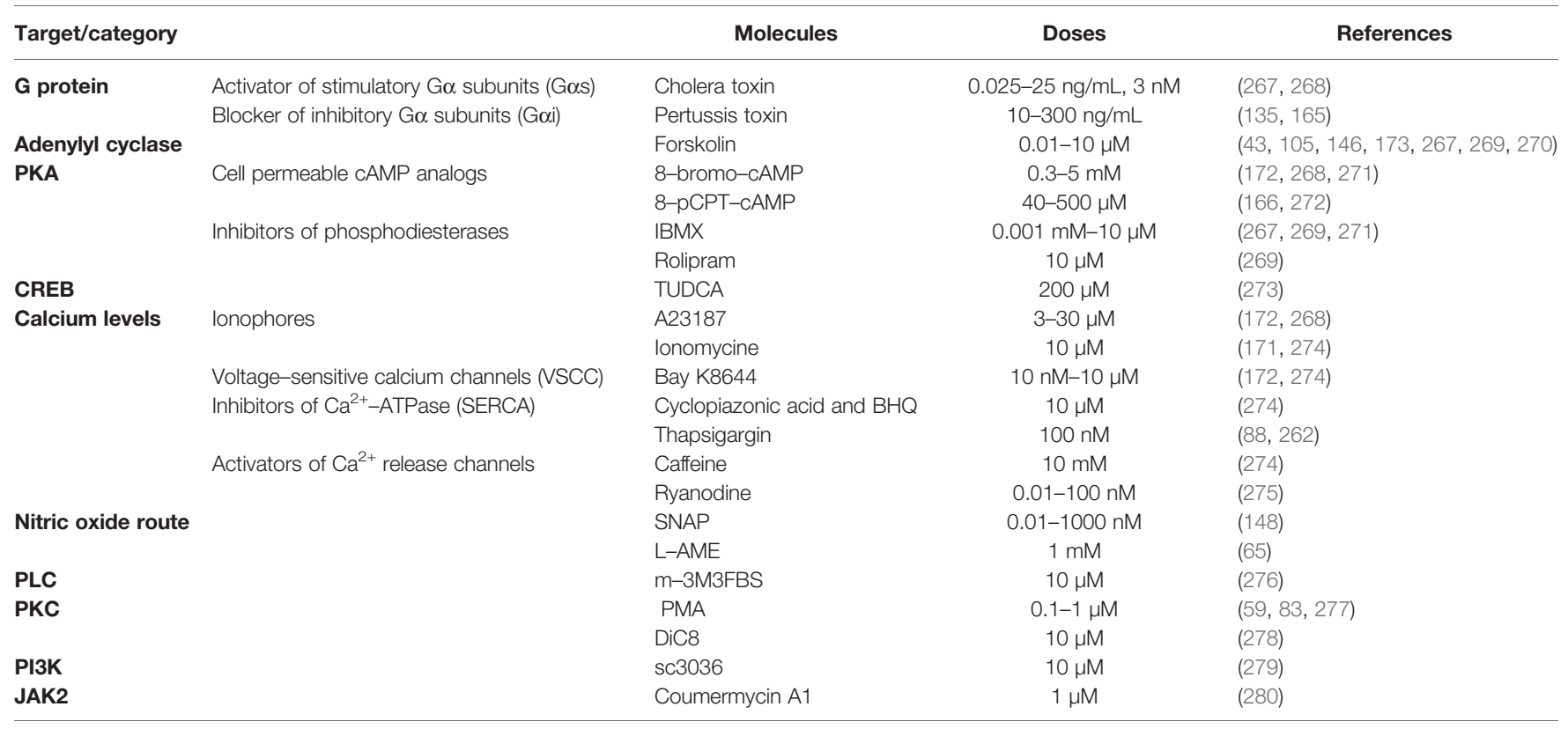

rat somatotrophs through the AC/PKA/CREB signaling pathway (166), suggesting that the mechanism of action of nesfatin-1 and nesfatin-1-like peptide involves a GPCR associated with an inhibitory $\mathrm{G} \alpha$-subunit ( $\mathrm{G} \alpha \mathrm{i}$ ). As discussed in the previous section, numerous pharmacological inhibitors were also used for the study of GH and somatotrophs (Figure 2). These are listed in Table 6.

\section{PERSPECTIVES}

While GH is a key endocrine regulator of somatic growth, it is also involved in the regulation of other vital processes in vertebrates. Thus, GH has implications in health, disease and even in animal production, and the fine-tuned control of GH synthesis and secretion is still a hot research topic more than 75 years after its discovery (1). Numerous $\mathrm{GH}$

TABLE 6 | Selection of GH signaling pathway inhibitors.

\begin{tabular}{|c|c|c|c|c|}
\hline Target/category & & Molecules & Doses & References \\
\hline \multirow[t]{2}{*}{ G protein } & Blocker of stimulatory $\mathrm{G} \alpha$ subunits (G $\alpha \mathrm{s}$ ) & Suramin, and its analogs & $10 \mu \mathrm{M}$ & $(283)$ \\
\hline & Activator of inhibitory $\mathrm{G} \alpha$ subunits (Goi) & Pasteurella multocida toxin & $1 \mathrm{nM}$ & $(284)$ \\
\hline Adenylyl cyclase & & MDL-12330A & $0.03-30 \mu \mathrm{M}$ & $(88,172,262)$ \\
\hline \multirow[t]{3}{*}{ PKA } & Blockers & $\mathrm{H} 89$ & $100 \mathrm{nM}-30 \mu \mathrm{M}$ & $(105,172,262,268)$ \\
\hline & & Rp-cAMP and DPT-PKI & $50 \mu \mathrm{M}-1 \mathrm{mM}$ & $(230,268)$ \\
\hline & Phosphodiesterase activator & MR-L2 & $1-10 \mu \mathrm{M}$ & $(285)$ \\
\hline CREB & & 2-naphthol-AS-E-phosphate & $25 \mu \mathrm{M}$ & $(286)$ \\
\hline \multirow[t]{6}{*}{ Calcium levels } & Cell permeable $\mathrm{Ca}^{2+-}$ chelator & BAPTA-AM & $10-50 \mu \mathrm{M}$ & $(135,171,274)$ \\
\hline & Voltage-sensitive calcium channels (VSCC) & Nifedipine and Verapamil & $1-100 \mu \mathrm{M}$ & $(130,230,262,271)$ \\
\hline & & $\mathrm{Ca}^{2+}$ antagonists $\mathrm{CoCl}_{2}$ and $\mathrm{CdCl}_{2}$ & $0.1-2 \mathrm{mM}$ & $(88,271)$ \\
\hline & Activator of $\mathrm{Ca}^{2+}$-ATPase (SERCA) & CDN1163 & $10 \mu \mathrm{M}$ & $(287)$ \\
\hline & Inhibitors of $\mathrm{Ca}^{2+}$ release channels & TMB-8 & $100 \mu \mathrm{M}$ & $(274)$ \\
\hline & & Xestopongin C & $1 \mu \mathrm{M}$ & $(275)$ \\
\hline \multirow[t]{2}{*}{ Nitric oxide route } & & NMMA & $0.3-1 \mathrm{mM}$ & $(148,268)$ \\
\hline & & NAME & $10 \mu \mathrm{M}$ & $(65)$ \\
\hline PLC & & U-73122 & $5-50 \mu \mathrm{M}$ & $(88,230,262)$ \\
\hline \multirow[t]{3}{*}{ PKC } & & GF109203X & $20 \mu \mathrm{M}$ & $(230)$ \\
\hline & & Phloretin & $25 \mu \mathrm{M}$ & $(262)$ \\
\hline & & $\mathrm{BIM}$ & $2 \mu \mathrm{M}$ & (268) \\
\hline \multirow[t]{2}{*}{ PI3K } & & Wortmannin & $10-100 \mathrm{nM}$ & $(146,164)$ \\
\hline & & LY294002 & $10 \mu \mathrm{M}$ & (164) \\
\hline JAK2 & & AG490 & $100 \mu \mathrm{M}$ & $(146)$ \\
\hline MEK1/2 & & PD98059, U0126 & $10 \mu \mathrm{M}$ & $(62,134,164)$ \\
\hline \multirow[t]{2}{*}{ p38 MAPK } & & SB202190 & $20 \mu \mathrm{M}$ & $(146)$ \\
\hline & & SB203580, PD169816 & $10 \mu \mathrm{M}$ & $(164)$ \\
\hline Transcription & & Actinomycin D & $8 \mu \mathrm{M}$ & $(129)$ \\
\hline
\end{tabular}


regulators have been discovered and more progress in our knowledge on $\mathrm{GH}$ and somatotroph biology is expected in the future. Definitively, the progress in our knowledge of GH and its transfer and application will benefit the society in many ways. The same reasons support the need for more basic, clinical and comparative endocrinology research on $\mathrm{GH}$ biology in vertebrates.

\section{AUTHOR CONTRIBUTIONS}

EV and SU prepared the manuscript, and EV created the tables and figures. All authors contributed to the article and approved the submitted version.

\section{REFERENCES}

1. Strobl JS, Thomas MJ. Human growth hormone. Pharmacol Rev (1994) 46:1-34.

2. Ergun-Longmire B, Wajnrajch MP. Growth and growth disorders. In: Endotext. Available at: https://www.ncbi.nlm.nih.gov/books/NBK279142/ (Accessed October 6, 2020).

3. Ayuk J, Sheppard MC. Growth hormone and its disorders. Postgrad Med J (2006) 82:24-30. doi: 10.1136/pgmj.2005.036087

4. Carroll PV, Jenkins PJ. Acromegaly. In: Endotext. MDText.com, Inc. Available at: http://www.ncbi.nlm.nih.gov/pubmed/25905322 (Accessed October 6, 2020).

5. Lu M, Flanagan JU, Langley RJ, Hay MP, Perry JK. Targeting growth hormone function: strategies and therapeutic applications. Signal Transduct Target Ther (2019) 4:1-11. doi: 10.1038/s41392-019-0036-y

6. Giustina A. Acromegaly and vertebral fractures: facts and questions. Trends Endocrinol Metab (2020) 31:274-5. doi: 10.1016/j.tem.2020.01.011

7. Ranke MB, Wit JM. Growth hormone-past, present and future. Nat Rev Endocrinol (2018) 14:285-300. doi: 10.1038/nrendo.2018.22

8. Cuevas-Ramos D, Fleseriu M. Somatostatin receptor ligands and resistance to treatment in pituitary adenomas. J Mol Endocrinol (2014) 52:R223-40. doi: 10.1530/JME-14-0011

9. Boguszewski CL. Update on GH therapy in adults. F1000Res (2017) 6:1-13. doi: 10.12688/f1000research.12057.1

10. Chernausek SD, Backeljauw PF, Frane J, Kuntze J, Underwood LE. Longterm treatment with recombinant insulin-like growth factor (IGF)-I in children with severe IGF-I deficiency due to growth hormone insensitivity. J Clin Endocrinol Metab (2007) 92:902-10. doi: 10.1210/jc.2006-1610

11. Aftab S, Prentice P, Katugampola H, Dattani M. Recombinant human Insulin-like growth factor-1 (rhIGF-1) therapy: a 15-year experience in a tertiary care centre. Endocr Abstr (2019) 66:32. doi: 10.1530/ endoabs.66.oc5.5

12. Mulligan K, Schambelan M. Anabolic treatment with GH, IGF-I, or anabolic steroids in patients with HIV-associated wasting. Int J Cardiol (2002) 85:151-9. doi: 10.1016/S0167-5273(02)00247-4

13. Le TN, Anabtawi A, Putman MS, Tangpricha V, Stalvey MS. Growth failure and treatment in cystic fibrosis. J Cyst Fibros (2019) 18:S82-7. doi: 10.1016/ j.jcf.2019.08.010

14. Canosa LF, Chang JP, Peter RE. Neuroendocrine control of growth hormone in fish. Gen Comp Endocrinol (2007) 151:1-26. doi: 10.1016/ j.ygcen.2006.12.010

15. Bergan-Roller HE, Sheridan MA. The growth hormone signaling system: Insights into coordinating the anabolic and catabolic actions of growth hormone. Gen Comp Endocrinol (2018) 258:119-33. doi: 10.1016/ j.ygcen.2017.07.028

16. Arámburo C, Alba-Betancourt C, Luna M, Harvey S. Expression and function of growth hormone in the nervous system: A brief review. Gen Comp Endocrinol (2014) 203:35-42. doi: 10.1016/j.ygcen.2014.04.035

17. Vélez EJ, Lutfi E, Azizi S, Perelló M, Salmerón C, Riera-Codina M, et al. Understanding fish muscle growth regulation to optimize aquaculture

\section{FUNDING}

EV is supported by postdoctoral fellowship (\#4530) and a Top-Up Incentive Award (\#5362) from the Saskatchewan Health Research Foundation (SHRF), and a postdoctoral fellowship (\#2019MFE-429976-71377) from the Canadian Institutes of Health Research (CIHR). SU is a University of Saskatchewan Centennial Enhancement Chair in Comparative Endocrinology, and the research on hormones in his laboratory has been funded by grants from the Natural Sciences and Engineering Research Council (NSERC), CIHR, Canada Foundation for Innovation, SHRF, and Ferring Pharmaceuticals.

production. Aquaculture (2017) 467:28-40. doi: 10.1016/j.aquaculture. 2016.07.004

18. Pérez-Sánchez J, Simó-Mirabet P, Naya-Català F, Martos-Sitcha JA, Perera E, Bermejo-Nogales A, et al. Somatotropic axis regulation unravels the differential effects of nutritional and environmental factors in growth performance of marine farmed fishes. Front Endocrinol (Lausanne) (2018) 9:1-24. doi: 10.3389/fendo.2018.00687

19. Martínez-Moreno CG, Calderón-Vallejo D, Harvey S, Arámburo C, Quintanar JL. Growth hormone (GH) and gonadotropin-releasing hormone $(\mathrm{GnRH})$ in the central nervous system: A potential neurological combinatory therapy? Int J Mol Sci (2018) 19:1-21. doi: 10.3390/ ijms 19020375

20. Harvey S, Martínez-Moreno CG, Luna M, Arámburo C. Autocrine/ paracrine roles of extrapituitary growth hormone and prolactin in health and disease: An overview. Gen Comp Endocrinol (2015) 220:103-11. doi: 10.1016/j.ygcen.2014.11.004

21. Canosa LF, Bertucci JI. Nutrient regulation of somatic growth in teleost fish. The interaction between somatic growth, feeding and metabolism. Mol Cell Endocrinol (2020) 518:111029. doi: 10.1016/j.mce.2020.111029

22. Dohoo IR, Leslie K, DesCôteaux L, Fredeen A, Dowling P, Preston A, et al. A meta-analysis review of the effects of recombinant bovine somatotropin. 1. Methodology and effects on production. Can J Vet Res (2003) 67:241-51.

23. Devlin RH, Biagi CA, Yesaki TY, Smailus DE, Byatt JC. Growth of domesticated transgenic fish. Nature (2001) 409:781-2. doi: 10.1038/ 35057314

24. Vélez EJ, Perelló M, Azizi S, Moya A, Lutfi E, Pérez-Sánchez J, et al. Recombinant bovine growth hormone (rBGH) enhances somatic growth by regulating the GH-IGF axis in fingerlings of gilthead sea bream (Sparus aurata). Gen Comp Endocrinol (2018) 257:192-202. doi: 10.1016/ j.ygcen.2017.06.019

25. Vélez EJ, Perelló-Amorós M, Lutfi E, Azizi S, Capilla E, Navarro I, et al. A long-term growth hormone treatment stimulates growth and lipolysis in gilthead sea bream juveniles. Comp Biochem Physiol-Part A Mol Integr Physiol (2019) 232:67-78. doi: 10.1016/j.cbpa.2019.03.012

26. Sheridan MA, Hagemeister AL. Somatostatin and somatostatin receptors in fish growth. Gen Comp Endocrinol (2010) 167:360-5. doi: 10.1016/ j.ygcen.2009.09.002

27. Dehkhoda F, Lee CMM, Medina J, Brooks AJ. The growth hormone receptor: Mechanism of receptor activation, cell signaling, and physiological aspects. Front Endocrinol (Lausanne) (2018) 9:35. doi: 10.3389/fendo.2018.00035

28. Steyn FJ, Tolle V, Chen C, Epelbaum J. Neuroendocrine regulation of growth hormone secretion. Compr Physiol (2016) 6:687-735. doi: 10.1002/ cphy.c150002

29. Harvey S. Growth hormone secretion in poikilotherms and homeotherms. In: Schreibman MP, Scanes CG and Pang PKT, editors. The Endocrinology of Growth, Development, and Metabolism in Vertebrates. San Diego, California: Academic Press. (1993) p. 151-82. doi: 10.1016/b978-0-12-629055-4. 50010-6

30. Schernthaner-Reiter MH, Trivellin G, Stratakis CA. Chaperones, somatotroph tumors and the cyclic AMP (cAMP)-dependent protein 
kinase (PKA) pathway. Mol Cell Endocrinol (2020) 499:110607. doi: 10.1016/j.mce.2019.110607

31. Peverelli E, Mantovani G, Lania AG, Spada A. cAMP in the pituitary: An old messenger for multiple signals. J Mol Endocrinol (2014) 52:R67-77. doi: 10.1530/JME-13-0172

32. Oldham WM, Hamm HE. Heterotrimeric G protein activation by Gprotein-coupled receptors. Nat Rev Mol Cell Biol (2008) 9:60-71. doi: 10.1038/nrm2299

33. Kato Y, Murakami Y, Sohmiya M, Nishiki M. Regulation of human growth hormone secretion and its disorders. Intern Med (2002) 41:7-13. doi: 10.2169/internalmedicine.41.7

34. Patel YC, Greenwood MT, Warszynska A, Panetta R, Srikant CB. All five cloned human somatostatin receptors (hSSTR1-5) are functionally coupled to adenylyl cyclase. Biochem Biophys Res Commun (1994) 198:605-12. doi: 10.1006/bbrc.1994.1088

35. Hernández-Ramírez LC, Trivellin G, Stratakis CA. Cyclic 3',5'-adenosine monophosphate (cAMP) signaling in the anterior pituitary gland in health and disease. Mol Cell Endocrinol (2018) 463:72-86. doi: 10.1016/ j.mce.2017.08.006

36. Shabb JB. Physiological substrates of cAMP-dependent protein kinase. Chem Rev (2001) 101:2381-411. doi: 10.1021/cr0002361

37. Bertherat J. Nuclear effects of the cAMP pathway activation in somatotrophs. Horm Res (1997) 47:245-50. doi: 10.1159/000185471

38. Gahete MD, Durán-Prado M, Luque RM, Martínez-Fuentes AJ, Quintero A, Gutiérrez-Pascual E, et al. Understanding the multifactorial control of growth hormone release by somatotropes: Lessons from comparative endocrinology. Ann N Y Acad Sci (2009) 1163:137-53. doi: 10.1111/ j.1749-6632.2008.03660.x

39. Argenton F, Vianello S, Bernardini S, Jacquemin P, Martial J, Belayew A, et al. The transcriptional regulation of the growth hormone gene is conserved in vertebrate evolution. Biochem Biophys Res Commun (1993) 192:1360-6. doi: 10.1006/bbrc.1993.1566

40. Wehrenberg WB, Seifert H, Bilezikjian LM, Vale W. Down-regulation of growth hormone releasing factor receptors following continuous infusion of growth hormone releasing factor in vivo. Neuroendocrinology (1986) 43:266-8. doi: 10.1159/000124538

41. Bilezikjian LM, Seifert H, Vale W. Desensitization to growth hormonereleasing factor (GRF) is associated with down-regulation of GRF-binding sites. Endocrinology (1986) 118:2045-52. doi: 10.1210/endo-118-5-2045

42. Martari M, Salvatori R. Diseases Associated with Growth HormoneReleasing Hormone Receptor (GHRHR) Mutations. Prog Mol Biol Transl Sci (2009) 88:57-84. doi: 10.1016/S1877-1173(09)88003-4

43. Aleppo G, Moskal SF, De Grandis PA, Kineman RD, Frohman LA. Homologous down-regulation of growth hormone-releasing hormone receptor messenger ribonucleic acid levels. Endocrinology (1997) 138:1058-65. doi: 10.1210/endo.138.3.5029

44. Córdoba-Chacón J, Gahete MD, Castaño JP, Kineman RD, Luque RM. Homologous and heterologous in vitro regulation of pituitary receptors for somatostatin, growth hormone (GH)-releasing hormone, and ghrelin in a nonhuman primate (Papio anubis). Endocrinology (2012) 153:264-72. doi: 10.1210/en.2011-1677

45. Rousseau K, Le Belle N, Marchelidon J, Dufour S. Evidence that corticotropin-releasing hormone acts as a growth hormone-releasing factor in a primitive teleost, the European eel (Anguilla anguilla). J Neuroendocrinol (1999) 11:385-92. doi: 10.1046/j.1365-2826.1999.00334.x

46. Cardenas R, Lin X, Canosa LF, Luna M, Arámburo C, Peter RE. Estradiol reduces pituitary responsiveness to somatostatin (SRIF-14) and downregulates the expression of somatostatin sst2 receptors in female goldfish pituitary. Gen Comp Endocrinol (2003) 132:119-24. doi: 10.1016/S00166480(03)00055-8

47. Holloway AC, Sheridan MA, Leatherland JF. Estradiol inhibits plasma somatostatin 14 (SRIF-14) levels and inhibits the response of somatotrophic cells to SRIF-14 challenge in vitro in rainbow trout, Oncorhynchus mykiss. Gen Comp Endocrinol (1997) 106:407-14. doi: 10.1006/gcen.1997.6881

48. Holmes RL, Ball JN. The Pituitary Gland, A Comparative Account (1974). LONDON/NEW YORK: CAMBRIDGE UNIVPRESS. Available at: https:// catalogue.nla.gov.au/Record/432193 (Accessed November 13, 2020).
49. Peter RE, Yu K-L, Marchant TA, Rosenblum PM. Direct neural regulation of the teleost adenohypophysis. J Exp Zool (1990) 256:84-9. doi: 10.1002/ jez.1402560415

50. Wong AOL, Zhou H, Jiang Y, Ko WKW. Feedback regulation of growth hormone synthesis and secretion in fish and the emerging concept of intrapituitary feedback loop. Comp Biochem Physiol - A Mol Integr Physiol (2006) 144:284-305. doi: 10.1016/j.cbpa.2005.11.021

51. Yunker WK, Lee EKY, Wong AOL, Chang JP. Norepinephrine regulation of growth hormone release from goldfish pituitary cells. II. Intracellular sites of action. J Neuroendocrinol (2000) 12:323-33. doi: 10.1046/j.13652826.2000.00456.x

52. Kah O, Dubourg P, Onteniente B, Geffard M, Calas A. The dopaminergic innervation of the goldfish pituitary - An immunocytochemical study at the electron-microscope level using antibodies against dopamine. Cell Tissue Res (1986) 244:577-82. doi: 10.1007/BF00212536

53. Ishibashi M, Yamaji T. Direct effects of catecholamines, thyrotropinreleasing hormone, and somatostatin on growth hormone and prolactin secretion from adenomatous and nonadenomatous human pituitary cells in culture. J Clin Invest (1984) 73:66-78. doi: 10.1172/JCI111208

54. Tsaneva-Atanasova K, Sherman A, Van Goor F, Stojilkovic SS. Mechanism of spontaneous and receptor-controlled electrical activity in pituitary somatotrophs: Experiments and theory. J Neurophysiol (2007) 98:131-44. doi: $10.1152 /$ jn. 00872.2006

55. Ben-Shlomo A, Melmed S. Pituitary somatostatin receptor signaling. Trends Endocrinol Metab (2010) 21:123-33. doi: 10.1016/j.tem.2009.12.003

56. Steyn FJ. Growth Hormone Releasing Hormone (GHRH). In: Choi S, editor. Encyclopedia of Signaling Molecules. Cham: Springer International Publishing (2018). p. 2271-5. doi: 10.1007/978-3-319-67199-4_101674

57. Fridlyand LE, Tamarina NA, Schally AV, Philipson LH. Growth hormonereleasing hormone in diabetes. Front Endocrinol (Lausanne) (2016) 7:129:129. doi: 10.3389/fendo.2016.00129

58. Rizzo M, Rizvi A, Sudar E, Soskic S, Obradovic M, Montalto G, et al. A review of the cardiovascular and anti-atherogenic effects of ghrelin. Curr Pharm Des (2013) 19:4953-63. doi: 10.2174/1381612811319270018

59. Tian C, Ye F, Xu T, Wang S, Wang X, Wang H, et al. GHRP-6 induces CREB phosphorylation and growth hormone secretion via a protein kinase $\mathrm{C} \sigma-$ dependent pathway in GH3 cells. J Huazhong Univ Sci Technol - Med Sci (2010) 30:183-7. doi: 10.1007/s11596-010-0210-5

60. Abizaid A, Hougland JL. Ghrelin signaling: GOAT and GHS-R1a take a LEAP in complexity. Trends Endocrinol Metab (2020) 31:107-17. doi: 10.1016/j.tem.2019.09.006

61. Hedegaard MA, Holst B. The complex signaling pathways of the ghrelin receptor. Endocrinology (2020) 161(4):bqaa020. doi: 10.1210/endocr/bqaa020

62. Chan CB, Leung PK, Wise H, Cheng CHK. Signal transduction mechanism of the seabream growth hormone secretagogue receptor. FEBS Lett (2004) 577:147-53. doi: 10.1016/j.febslet.2004.08.088

63. Hartt DJ, Ogiwara T, Ho AK, Chik CL. Cyclic GMP stimulates growth hormone release in rat anterior pituitary cells. Biochem Biophys Res Commun (1995) 214:918-26. doi: 10.1006/bbrc.1995.2374

64. Malagón MM, Vázquez-Martínez R, Martínez-Fuentes AJ, Gracia-Navarro F, Castaño JP. Growth Hormone-Releasing Hormone. In: Kastin AJ, editor. Handbook of Biologically Active Peptides. San Diego, California: Academic Press. (2006) p. 663-671. doi: 10.1016/B978-012369442-3/50096-9

65. Luque RM, Pacheco-Rodríguez F, Tena-Sempere M, Gracia-Navarro F, Malagón MM, Castaño JP. Differential contribution of nitric oxide and cGMP to the stimulatory effects of growth hormone-releasing hormone and low-concentration somatostatin on growth hormone release from somatotrophs. J Neuroendocrinol (2005) 17:577-82. doi: 10.1111/j.13652826.2005.01345. $\mathrm{x}$

66. Jansson JO, Edén S, Isaksson O. Sexual dimorphism in the control of growth hormone secretion. Endocr Rev (1985) 6:128-50. doi: 10.1210/edrv-6-2-128

67. Jaffe CA, Ocampo-Lim B, Guo W, Krueger K, Sugahara I, DeMott-Friberg $\mathrm{R}$, et al. Regulatory mechanisms of growth hormone secretion are sexually dimorphic. J Clin Invest (1998) 102:153-64. doi: 10.1172/JCI2908

68. Hindmarsh PC, Dennison E, Pincus SM, Cooper C, Fall CHD, Matthews $\mathrm{DR}$, et al. A sexually dimorphic pattern of growth hormone secretion in the elderly. J Clin Endocrinol Metab (1999) 84:2679-85. doi: 10.1210/ jcem.84.8.5915 
69. anchez-Cardenas C, Fontanaud P, He Z, Lafont C, Meunier AC, Schaeffer M, et al. Pituitary growth hormone network responses are sexually dimorphic and regulated by gonadal steroids in adulthood. Proc Natl Acad Sci USA (2010) 107:21878-83. doi: 10.1073/pnas.1010849107

70. Argente J, Chowen JA, Zeitlerj P, Clifton DK, Steiner RA. Sexual dimorphism of growth hormone-releasing hormone and somatostatin gene expression in the hypothalamus of the rat during development. Endocrinology (1991) 128:2369-75. doi: 10.1210/endo-128-5-2369

71. Guillemin R, Brazeau P, Böhlen P, Esch F, Ling N, Wehrenberg WB. Growth hormone-releasing factor from a human pancreatic tumor that caused acromegaly. Science (80-) (1982) 218:585-7. doi: 10.1126/science.6812220

72. Rivier J, Spiess J, Thorner M, Vale W. Characterization of a growth hormone-releasing factor from a human pancreatic islet tumour. Nature (1982) 300:276-8. doi: 10.1038/300276a0

73. Lee LTO, Siu FKY, Tam JKV, Lau ITY, Wong AOL, Lin MCM, et al. Discovery of growth hormone-releasing hormones and receptors in nonmammalian vertebrates. Proc Natl Acad Sci USA (2007) 104:2133-8. doi: 10.1073/pnas.0611008104

74. Ávila-Mendoza J, Pérez-Rueda E, Urban-Sosa V, Carranza M, MartínezMoreno CG, Luna M, et al. Characterization and distribution of GHRH, PACAP, TRH, SST and IGF1 mRNAs in the green iguana. Gen Comp Endocrinol (2018) 255:90-101. doi: 10.1016/j.ygcen.2017.09.027

75. Lessi M, Giordano M, Momigliano-Richiardi P, Paracchini R, Bona G, Petri A, et al. Molecular analysis of the growth hormone releasing hormone receptor gene (GHRH-R) in isolated growth hormone deficiency: identification of a likely etiological mutation in the signal peptide. Int $J$ Disabil Hum Dev (2001) 2:215-28. doi: 10.1515/IJDHD.2001.2.4.215

76. Jeandel L, Okuno A, Kobayashi T, Kikuyama S, Tostivint H, Lihrmann I, et al. Effects of the two somatostatin variants somatostatin-14 and [Pro2, Met13]somatostatin-14 on receptor binding, adenylyl cyclase activity and growth hormone release from the frog pituitary. J Neuroendocrinol (1998) 10:187-92. doi: 10.1046/j.1365-2826.1998.00188.x

77. Denver RJ, Licht P. Modulation of neuropeptide-stimulated pituitary hormone secretion in hatchling turtles. Gen Comp Endocrinol (1990) 77:107-15. doi: 10.1016/0016-6480(90)90211-4

78. Sosa VAU, Mendoza JA, Salas MC, Moreno CGM, Munoz ML, Aramburo C. Comparative differential effects of secretagogues upon regulation of pituitary GH in several vertebrates. Endocr Abstr (2018) 56:433. doi: 10.1530/ endoabs.56.p778

79. Smith RG, Feighner S, Prendergast K, Guan X, Howard A. A new orphan receptor involved in pulsatile growth hormone release. Trends Endocrinol Metab (1999) 10:128-35. doi: 10.1016/S1043-2760(98)00132-5

80. Brazeau P, Vale W, Burgus R, Ling N, Butcher M, Rivier J, et al. Hypothalamic polypeptide that inhibits the secretion of immunoreactive pituitary growth hormone. Science (80-) (1973) 179:77-9. doi: 10.1126/ science.179.4068.77

81. Luque RM, Peinado JR, Gracia-Navarro F, Broglio F, Ghigo E, Kineman RD, et al. Cortistatin mimics somatostatin by inducing a dual, dose-dependent stimulatory and inhibitory effect on growth hormone secretion in somatotropes. J Mol Endocrinol (2006) 36:547-56. doi: 10.1677/jme.1.01980

82. Yada $T$, Hirano $T$. Inhibition of growth hormone synthesis by somatostatin in cultured pituitary of rainbow trout. J Comp Physiol B (1992) 162:575-80. doi: 10.1007/BF00296636

83. Rousseau K, Le Belle N, Pichavant K, Marchelidon J, Chow BKC, Boeuf G, et al. Pituitary growth hormone secretion in the turbot, a phylogenetically recent teleost, is regulated by a species-specific pattern of neuropeptides. Neuroendocrinology (2001) 74:375-85. doi: 10.1159/000054704

84. Tannenbaum GS. Somatostatin as a physiological regulator of pulsatile growth hormone secretion. Horm Res Paediatr (1988) 29:70-4. doi: 10.1159/000180971

85. MacGregor DJ, Leng G. Modelling the hypothalamic control of growth hormone secretion. J Neuroendocrinol (2005) 17:788-803. doi: 10.1111/ j.1365-2826.2005.01370.x

86. Osterstock G, Mitutsova V, Barre A, Granier M, Fontanaud P, Chazalon M, et al. Somatostatin triggers rhythmic electrical firing in hypothalamic GHRH neurons. Sci Rep (2016) 6:24394. doi: 10.1038/srep24394

87. Goldenberg N, Barkan A. Factors regulating growth hormone secretion in humans. Endocrinol Metab Clin North Am (2007) 36:37-55. doi: 10.1016/ j.ecl.2006.11.003
88. Ramírez JL, Gracia-Navarro F, García-Navarro S, Torronteras R, Malagón MM, Castaño JP. Somatostatin stimulates GH secretion in two porcine somatotrope subpopulations through a cAMP-dependent pathway. Endocrinology (2002) 143:889-97. doi: 10.1210/endo.143.3.8685

89. Park S, Jiang H, Zhang H, Smith RG. Modification of ghrelin receptor signaling by somatostatin receptor-5 regulates insulin release. Proc Nat Acad Sci USA (2012) 109:19003-8. doi: 10.1073/pnas.1209590109

90. Jaquet P, Gunz G, Saveanu A, Dufour H, Taylor J, Dong J, et al. Efficacy of chimeric molecules directed towards multiple somatostatin and dopamine receptors on inhibition of $\mathrm{GH}$ and prolactin secretion from $\mathrm{GH}$-secreting pituitary adenomas classified as partially responsive to somatostatin analog therapy. Eur J Endocrinol (2005) 153:135-41. doi: 10.1530/eje.1.01950

91. Saveanu A, Lavaque E, Gunz G, Barlier A, Kim S, Taylor JE, et al. Demonstration of enhanced potency of a chimeric somatostatindopamine molecule, BIM-23A387, in suppressing growth hormone and prolactin secretion from human pituitary somatotroph adenoma cells. J Clin Endocrinol Metab (2002) 87:5545-52. doi: 10.1210/jc.2002-020934

92. Rubinek T, Modan-Moses D. Klotho and the growth hormone/insulin-like growth factor 1 axis: Novel insights into complex interactions. Vitam Horm (2016) 101:85-118. doi: 10.1016/bs.vh.2016.02.009

93. Pérez-Sánchez J, Marti-Palanca H, Le Bail PY. Seasonal changes in circulating growth hormone $(\mathrm{GH})$, hepatic $\mathrm{GH}$-binding and plasma insulin-like growth factor-I immunoreactivity in a marine fish, gilthead sea bream, Sparus aurata. Fish Physiol Biochem (1994) 13:199-208. doi: 10.1007/BF00004358

94. Mingarro M, Vega-Rubín de Celis S, Astola A, Pendón C, Valdivia MM, Pérez-Sánchez J. Endocrine mediators of seasonal growth in gilthead sea bream (Sparus aurata): the growth hormone and somatolactin paradigm. Gen Comp Endocrinol (2002) 128:102-11. doi: 10.1016/S0016-6480(02) 00042-4

95. Stacey NE, MacKenzie DS, Marchant TA, Kyle L, Peter RE. Endocrine changes during natural spawning in the white sucker, Catostomus commersoni. I. Gonadotropin, growth hormone, and thyroid hormones. Gen Comp Endocrinol (1984) 56:333-48. doi: 10.1016/0016-6480(84)90076-5

96. Lin SW, Ge W. Differential regulation of gonadotropins (FSH and LH) and growth hormone $(\mathrm{GH})$ by neuroendocrine, endocrine, and paracrine factors in the zebrafish-An in vitro approach. Gen Comp Endocrinol (2009) 160:183-93. doi: 10.1016/j.ygcen.2008.11.020

97. Triantaphyllopoulos KA, Cartas D, Miliou H. Factors influencing GH and IGF-I gene expression on growth in teleost fish: how can aquaculture industry benefit? Rev Aquac (2019) 12(3):raq.12402. doi: 10.1111/raq.12402

98. Scanes CG, Proudman JA, Radecki SV. Influence of continuous growth hormone or insulin-like growth factor I administration in adult female chickens. Gen Comp Endocrinol (1999) 114:315-23. doi: 10.1006/ gcen.1999.7259

99. Kühn ER, Geelissen SME, Van Der Geyten S, Darras VM. The release of growth hormone $(\mathrm{GH})$ : Relation to the thyrotropic-and corticotropic axis in the chicken. Domest Anim Endocrinol (2005) 29:43-51. doi: 10.1016/ j.domaniend.2005.02.022

100. Yamashita S, Melmed S. Insulinlike growth factor I regulation of growth hormone gene transcription in primary rat pituitary cells. J Clin Invest (1987) 79:449-52. doi: 10.1172/JCI112832

101. Duan C, Ren H, Gao S. Insulin-like growth factors (IGFs), IGF receptors, and IGF-binding proteins: roles in skeletal muscle growth and differentiation. Gen Comp Endocrinol (2010) 167:344-51. doi: 10.1016/ j.ygcen.2010.04.009

102. Ágústsson T, Björnsson BT. Growth hormone inhibits growth hormone secretion from the rainbow trout pituitary in vitro. Comp Biochem PhysiolC Pharmacol Toxicol Endocrinol (2000) 126:299-303. doi: 10.1016/S07428413(00)00120-1

103. Baudet ML, Harvey S. Ghrelin-induced GH secretion in domestic fowl in vivo and in vitro. J Endocrinol (2003) 179:97-105. doi: 10.1677/joe.0.1790097

104. Bertucci JI, Blanco AM, Sundarrajan L, Rajeswari JJ, Velasco C, Unniappan S. Nutrient regulation of endocrine factors influencing feeding and growth in fish. Front Endocrinol (Lausanne) (2019) 10:83:83. doi: 10.3389/ fendo.2019.00083

105. Melamed P, Gur G, Elizur A, Rosenfeld H, Sivan B, Rentier-Delrue F, et al. Differential effects of gonadotropin-releasing hormone, dopamine and 
somatostatin and their second messengers on the mRNA levels of gonadotropinII $\beta$ subunit and growth hormone in the teleost fish, tilapia. Neuroendocrinology (1996) 64:320-8. doi: 10.1159/000127135

106. Lee EKY, Chan VCC, Chang JP, Yunker WK, Wong AOL. Norepinephrine regulation of growth hormone release from goldfish pituitary cells. I. Involvement of $\alpha 2$ adrenoreceptor and interactions with dopamine and salmon gonadotropin-releasing hormone. J Neuroendocrinol (2000) 12:31122. doi: 10.1046/j.1365-2826.2000.00455.x

107. Otto CJ, Lin X, Peter RE. Dopaminergic regulation of three somatostatin mRNAs in goldfish brain. Regul Pept (1999) 83:97-104. doi: 10.1016/S01670115(99)00052-X

108. Lin XW, Lin HR, Peter RE. Growth hormone and gonadotropin secretion in the common carp (Cyprinus carpio L.): In vitro interactions of gonadotropinreleasing hormone, somatostatin, and the dopamine agonist apomorphine. Gen Comp Endocrinol (1993) 89:62-71. doi: 10.1006/gcen.1993.1009

109. Hall TR, Chadwick A. Effects of synthetic mammalian thyrotrophin releasing hormone, somatostatin and dopamine on the secretion of prolactin and growth hormone from amphibian and reptilian pituitary glands incubated in vitro. J Endocrinol (1984) 102:175-80. doi: 10.1677/joe.0.1020175

110. Donoghue DJ, Perez FM, Diamante BSA, Malamed S, Scanes CG. Influence of catecholamines, prostaglandins and thyroid hormones on growth hormone secretion by chicken pituitary cells in vitro. Domest Anim Endocrinol (1990) 7:35-42. doi: 10.1016/0739-7240(90)90052-2

111. Arihara Z, Sakurai K, Yamashita R, Niitsuma S, Ueno T, Yamamura N, et al. Bromocriptine, A dopamine agonist, Increases growth hormone secretion in a patient with acromegaly. Tohoku J Exp Med (2014) 234:129-35. doi: $10.1620 /$ tjem.234.129

112. Bicknell RJ, Chapman C. Bombesin stimulates growth hormone secretion from cultured bovine pituitary cells. Neuroendocrinology (1983) 36:33-8. doi: $10.1159 / 000123433$

113. Pintér I, Makara GB, Ács Z. Acetylcholine stimulates growth hormone secretion in the neonatal rat pituitary. J Neuroendocrinol (1996) 8:935-9. doi: 10.1111/j.1365-2826.1996.tb00824.x

114. Broglio F, Gottero C, Van Koetsveld P, Prodam F, Destefanis S, Benso A, et al. Acetylcholine regulates ghrelin secretion in humans. J Clin Endocrinol Metab (2004) 89:2429-33. doi: 10.1210/jc.2003-031517

115. Lecomte MJ, Bertolus C, Ramanantsoa N, Saurini F, Callebert J, SénamaudBeaufort C, et al. Acetylcholine Modulates the Hormones of the Growth Hormone/Insulinlike Growth Factor-1 Axis during Development in Mice. Endocrinology (2018) 159:1844-59. doi: 10.1210/en.2017-03175

116. de Zegher F, Van Den Berghe G, Devlieger H, Eggermont E, Veldhuis JD. Dopamine inhibits growth hormone and prolactin secretion in the human newborn. Pediatr Res (1993) 34:642-5. doi: 10.1203/00006450-199311000-00016

117. Holloway AC, Leatherland JF. The effects of N-methyl-D-,L-aspartate and gonadotropin-releasing hormone on in vitro growth hormone release in steroid-primed immature rainbow trout, Oncorhynchus mykiss. Gen Comp Endocrinol (1997) 107:32-43. doi: 10.1006/gcen.1997.6907

118. Xiao D, Lin HR. Cysteamine - A somatostatin-inhibiting agent - Induced growth hormone secretion and growth acceleration in juvenile grass carp (Ctenopharyngodon idellus). Gen Comp Endocrinol (2003) 134:285-95. doi: 10.1016/S0016-6480(03)00268-5

119. Xiao D, Lin HR. Effects of cysteamine - A somatostatin-inhibiting agent On serum growth hormone levels and growth in juvenile grass carp (Ctenopharyngodon idellus). Comp Biochem Physiol - A Mol Integr Physiol (2003) 134:93-9. doi: 10.1016/S1095-6433(02)00191-5

120. Oh HS, Oh SK, Lee JS, Wu C, Lee SJ. Effects of l-arginine on growth hormone and insulin-like growth factor 1. Food Sci Biotechnol (2017) 26:1749-54. doi: 10.1007/s10068-017-0236-6

121. Adrião M, Chrisman CJS, Bielavsky M, Olinto SCF, Shiraishi EM, Nunes MT. Arginine increases growth hormone gene expression in rat pituitary and GH3 cells. Neuroendocrinology (2004) 79:26-33. doi: 10.1159/000076043

122. McLeod KR, Harmon DL, Schillo KK, Mitchell GE. Cysteamine-induced depletion of somatostatin in sheep: time course of depletion and changes in plasma metabolites, insulin, and growth hormone. J Anim Sci (1995) 73:7787. doi: $10.2527 / 1995.73177 \mathrm{x}$

123. Canosa LF, Peter RE. Effects of cholecystokinin and bombesin on the expression of preprosomatostatin-encoding genes in goldfish forebrain. Regul Pept (2004) 121:99-105. doi: 10.1016/j.regpep.2004.04.011
124. Canosa LF, Unniappan S, Peter RE. Periprandial changes in growth hormone release in goldfish: Role of somatostatin, ghrelin, and gastrin-releasing peptide. Am J Physiol - Regul Integr Comp Physiol (2005) 289:125-33. doi: 10.1152/ajpregu.00759.2004

125. Himick BA, Golosinski AA, JoNssoN AC, Peter RE. CCK/gastrin-like immunoreactivity in the goldfish pituitary: Regulation of pituitary hormone secretion by CCK-like peptides in vitro. Gen Comp Endocrinol (1993) 92:88-103. doi: 10.1006/gcen.1993.1146

126. Morley JE, Melmed S, Briggs J, Carlson HE, Hershman JM, Solomon TE, et al. Cholecystokinin octapeptide releases growth hormone from the pituitary in vitro. Life Sci (1979) 25:1201-5. doi: 10.1016/0024-3205(79)90461-2

127. Ge W, Peter RE. Activin-like peptides in somatotrophs and activin stimulation of growth hormone release in goldfish. Gen Comp Endocrinol (1994) 95:213-21. doi: 10.1006/gcen.1994.1118

128. Tamura N, Irahara M, Kuwahara A, Ushigoe K, Sugino H, Aono T. Effect of activin on production and secretion of prolactin and growth hormone in cultured rat GH3 cells. Eur J Endocrinol (2000) 142:506-11. doi: 10.1530/ eje. 0.1420506

129. Peng JP, Yang P, Zhang Q, Jiang Q. Tilapia adropin: the localization and regulation of growth hormone gene expression in pituitary cells. Peptides (2017) 97:1-7. doi: 10.1016/j.peptides.2017.09.009

130. Chang JP, Mar A, Wlasichuk M, Wong AOL. Kisspeptin-1 directly stimulates LH and GH secretion from goldfish pituitary cells in a Ca2+-dependent manner. Gen Comp Endocrinol (2012) 179:38-46. doi: 10.1016/j.ygcen.2012.07.028

131. Yang B, Jiang Q, Chan T, Ko WKW, Wong AOL. Goldfish kisspeptin: Molecular cloning, tissue distribution of transcript expression, and stimulatory effects on prolactin, growth hormone and luteinizing hormone secretion and gene expression via direct actions at the pituitary level. Gen Comp Endocrinol (2010) 165:60-71. doi: 10.1016/j.ygcen.2009.06.001

132. Gutiérrez-Pascual E, Martínez-fuentes AJ, Pinilla L, Tena-Sempere M, Malagón MM, Castaño JP. Direct pituitary effects of kisspeptin: Activation of gonadotrophs and somatotrophs and stimulation of luteinising hormone and growth hormone secretion. J Neuroendocrinol (2007) 19:521-30. doi: 10.1111/j.1365-2826.2007.01558.x

133. Foradori CD, Whitlock BK, Daniel JA, Zimmerman AD, Jones MA, Read $\mathrm{CC}$, et al. Kisspeptin stimulates growth hormone release by utilizing neuropeptide y pathways and is dependent on the presence of ghrelin in the ewe. Endocrinology (2017) 158:3526-39. doi: 10.1210/en.2017-00303

134. Shahmoon S, Rubinfeld H, Wolf I, Cohen ZR, Hadani M, Shimon I, et al. The aging suppressor klotho: A potential regulator of growth hormone secretion. Am J Physiol - Endocrinol Metab (2014) 307:326-34. doi: 10.1152/ ajpendo.00090.2014

135. Florio T, Casagrande S, Diana F, Bajetto A, Porcile C, Zona G, et al. Chemokine stromal cell-derived factor $1 \alpha$ induces proliferation and growth hormone release in $\mathrm{GH} 4 \mathrm{C} 1$ rat pituitary adenoma cell line through multiple intracellular signals. Mol Pharmacol (2006) 69:539-46. doi: 10.1124/ mol.105.015255

136. Lee Y, Kim JM, Lee EJ. Functional expression of CXCR4 in somatotrophs: CXCL12 activates GH gene, GH production and secretion, and cellular proliferation. J Endocrinol (2008) 199:191-9. doi: 10.1677/JOE-08-0250

137. ThanThan S, Mekaru C, Seki N, Hidaka K, Ueno A, ThidarMyint H, et al. Endogenous ghrelin released in response to endothelin stimulates growth hormone secretion in cattle. Domest Anim Endocrinol (2010) 38:1-12. doi: 10.1016/j.domaniend.2009.07.007

138. Zhao H, ThanThan S, Yannaing S, Kuwayama H. Involvement of endothelin $B$ receptors in the endothelin-3-induced increase of ghrelin and growth hormone in Holstein steers. Peptides (2010) 31:938-43. doi: 10.1016/ j.peptides.2010.02.005

139. Mensah E, Volkoff H, Unniappan S. "Galanin Systems in Non-mammalian Vertebrates with Special Focus on Fishes”. In: Hökfelt T, editor. Galanin. Basel, Switzerland: Springer, Basel. (2010) p. 243-262. doi: 10.1007/978-30346-0228-0_17

140. Cheung A, Hall TR. Direct stimulation of growth hormone secretion by galanin in the domestic fowl. J Neuroendocrinol (1990) 2:285-9. doi: 10.1111/ j.1365-2826.1990.tb00406.x

141. Gabriel SM, Milbury CM, Nathanson JA, Martin JB. Galanin stimulates rat pituitary growth hormone secretion in vitro. Life Sci (1988) 42:1981-6. doi: $10.1016 / 0024-3205(88) 90497-3$ 
142. Baratta M, Saleri R, Mascadri C, Coy DH, Andres NV, Tamanini C, et al. Modulation by galanin of growth hormone and gonadotropin secretion from perifused pituitary and median eminence of prepubertal male calves. Neuroendocrinology (1997) 66:271-7. doi: 10.1159/000127248

143. Hulting AL, Meister B, Carlsson L, Hilding A, Isaksson O. On the role of the peptide galanin in regulation of growth hormone secretion. Acta Endocrinol (Copenh) (1991) 125:518-25. doi: 10.1530/acta.0.1250518

144. Tanoh T, Shimatsu A, Ishikawa Y, Ihara C, Yanaihara N, Imura H. Galanininduced growth hormone secretion in conscious rats: evidence for a possible involvement of somatostatin. J Neuroendocrinol (1993) 5:183-7. doi: 10.1111/j.1365-2826.1993.tb00379.x

145. Cho SJ, Lee JS, Mathias ED, Chang C, Hickey GJ, Lkhagvadorj S, et al. Intracerebroventricular and intravenous administration of growth hormone secretagogue L-692,585, somatostatin, neuropeptide Y and galanin in pig: Dosedependent effects on growth hormone secretion. Comp Biochem Physiol - C Toxicol Pharmacol (2010) 151:412-9. doi: 10.1016/j.cbpc.2010.01.002

146. Zhou H, Jiang Y, Ko WKW, Li W, Wong AOL. Paracrine regulation of growth hormone gene expression by gonadotrophin release in grass carp pituitary cells: Functional implications, molecular mechanisms and signal transduction. J Mol Endocrinol (2005) 34:415-32. doi: 10.1677/jme.1.01629

147. Saleri R, Giustina A, Tamanini C, Valle D, Burattin A, Wehrenberg WB, et al. Leptin stimulates growth hormone secretion via a direct pituitary effect combined with a decreased somatostatin tone in a median eminence-pituitary perifusion study. Neuroendocrinology (2004) 79:221-8. doi: 10.1159/000078103

148. Baratta M, Saleri R, Mainardi GL, Valle D, Giustina A, Tamanini C. Leptin regulates $\mathrm{GH}$ gene expression and secretion and nitric oxide production in pig pituitary cells. Endocrinology (2002) 143:551-7. doi: 10.1210/endo.143.2.8653

149. Henry BA, Goding JW, Tilbrook AJ, Dunshea FR, Clarke IJ. Intracerebroventricular infusion of leptin elevates the secretion of luteinising hormone without affecting food intake in long-term food-restricted sheep, but increases growth hormone irrespective of bodyweight. J Endocrinol (2001) 168:6777. doi: $10.1677 /$ joe. 0.1680067

150. Zieba DA, Amstalden M, Morton S, Gallino JL, Edwards JF, Harms PG, et al. Effects of leptin on basal and GHRH-stimulated GH secretion from the bovine adenohypophysis are dependent upon nutritional status. J Endocrinol (2003) 178:83-9. doi: 10.1677/joe.0.1780083

151. Odle AK, Allensworth-James ML, Mohsin NA, Haney SAC, Macnicol M, Macnicol AM, et al. A sex-dependent, tropic role for leptin in the somatotrope as a regulator of POU1F1 and POU1F1-dependent hormones. Endocrinology (2016) 157:3958-71. doi: 10.1210/en.2016-1472

152. Luque RM, Huang ZH, Shah B, Mazzone T, Kineman RD. Effects of leptin replacement on hypothalamic-pituitary growth hormone axis function and circulating ghrelin levels in ob/ob mice. Am J Physiol - Endocrinol Metab (2007) 292(3):E891-9. doi: 10.1152/ajpendo.00258.2006

153. Eckert SM, Hirano T, Leedom TA, Takei Y, Grau EG. Effects of angiotensin II and natriuretic peptides of the eel on prolactin and growth hormone release in the tilapia, Oreochromis mossambicus. Gen Comp Endocrinol (2003) 130:333-9. doi: 10.1016/S0016-6480(02)00630-5

154. Soyoola EO, Burgess MF, Bird RC, Kemppainen RJ, Williams JC, Sartin JL. Neurotransmitter receptor agonists regulate growth hormone gene expression in cultured ovine pituitary cells. Proc Soc Exp Biol Med (1994) 207:26-33. doi: 10.3181/00379727-207-43786

155. Jin J, Hashizume T. Effects of hypothalamic dopamine on growth hormonereleasing hormone-induced growth hormone secretion and thyrotropinreleasing hormone-induced prolactin secretion in goats. Anim Sci J (2015) 86:634-40. doi: 10.1111/asj.12333

156. Ben-Shlomo A, Liu NA, Melmed S. Somatostatin and dopamine receptor regulation of pituitary somatotroph adenomas. Pituitary (2017) 20:93-9. doi: $10.1007 /$ s11102-016-0778-2

157. Somoza GM, Peter RE. Effects of serotonin on gonadotropin and growth hormone release from in vitro perifused goldfish pituitary fragments. Gen Comp Endocrinol (1991) 82:103-10. doi: 10.1016/0016-6480(91)90301-L

158. Hall TR, Harvey S, Chadwick A. Serotonin and acetylcholine affect the release of prolactin and growth hormone from pituitary glands of domestic fowl in vitro in the presence of hypothalamic tissue. Acta Endocrinol (Copenh) (1984) 105:455-62. doi: 10.1530/acta.0.1050455

159. Spencer GSG, Berry C, Johnston S. Neuroendocrine regulation of growth hormone secretion in sheep. IV. Central and peripheral cholecystokinin.
Domest Anim Endocrinol (1991) 8:555-63. doi: 10.1016/0739-7240(91) 90025-F

160. Hulting AL, Grenbäck E, Pineda J, Coya R, Hökfelt T, Meister B, et al. Effect of oxytocin on growth hormone release in vitro. Regul Pept (1996) 67:69-73. doi: 10.1016/S0167-0115(96)00112-7

161. Struthers RS, Gaddy-Kurten D, Vale WW. Activin inhibits binding of transcription factor Pit-1 to the growth hormone promoter. Proc Natl Acad Sci U.S.A. (1992) 89:11451-5. doi: 10.1073/pnas.89.23.11451

162. Douros JD, Baltzegar DA, Mankiewicz J, Taylor J, Yamaguchi Y, Lerner DT, et al. Control of leptin by metabolic state and its regulatory interactions with pituitary growth hormone and hepatic growth hormone receptors and insulin like growth factors in the tilapia (Oreochromis mossambicus). Gen Comp Endocrinol (2017) 240:227-37. doi: 10.1016/j.ygcen.2016.07.017

163. Smith JT, Roseweir A, Millar M, Clarke IJ, Millar RP. Stimulation of growth hormone by kisspeptin antagonists in ewes. J Endocrinol (2018) 237:165-73. doi: 10.1530/JOE-18-0074

164. Lian A, Li X, Jiang Q. Irisin inhibition of growth hormone secretion in cultured tilapia pituitary cells. Mol Cell Endocrinol (2017) 439:395-406. doi: 10.1016/j.mce.2016.09.030

165. Taylor MM, Bagley SL, Samson WK. Intermedin/adrenomedullin-2 inhibits growth hormone release from cultured, primary anterior pituitary cells. Endocrinology (2006) 147:859-64. doi: 10.1210/en.2005-0949

166. Vélez EJ, Unniappan S. Nesfatin-1 and nesfatin-1-like peptide suppress growth hormone synthesis via the AC/PKA/CREB pathway in mammalian somatotrophs. Sci Rep (2020) 10:16686. doi: 10.1038/s41598-020-73840-4

167. Miyata A, Arimura A, Dahl RR, Minamino N, Uehara A, Jiang L, et al. Isolation of a novel 38 residue-hypothalamic polypeptide which stimulates adenylate cyclase in pituitary cells. Biochem Biophys Res Commun (1989) 164:567-74. doi: 10.1016/0006-291X(89)91757-9

168. Miyata A, Jiang L, Dahl RD, Kitada C, Kubo K, Fujino M, et al. Isolation of a neuropeptide corresponding to the $\mathrm{N}$-terminal 27 residues of the pituitary adenylate cyclase activating polypeptide with 38 residues (PACAP38). Biochem Biophys Res Commun (1990) 170:643-8. doi: 10.1016/0006-291X(90)92140-U

169. Vaudry D, Falluel-Morel A, Bourgault S, Basille M, Burel D, Wurtz O, et al. Pituitary adenylate cyclase-activating polypeptide and its receptors: 20 Years after the discovery. Pharmacol Rev (2009) 61:283-357. doi: 10.1124/pr.109.001370

170. Montero M, Yon L, Kikuyama S, Dufour S, Vaudry H. Molecular evolution of the growth hormone-releasing hormone/pituitary adenylate cyclaseactivating polypeptide gene family. Functional implication in the regulation of growth hormone secretion. J Mol Endocrinol (2000) 25:15768. doi: 10.1677/jme.0.0250157

171. Yunker WK, Chang JP. Somatostatin-14 actions on dopamine- and pituitary adenylate cyclase-activating polypeptide-evoked ca2+ signals and growth hormone secretion. J Neuroendocrinol (2004) 16:684-94. doi: 10.1111/j.1365-2826.2004.01218.x

172. Wong AOL, Li W, Leung CY, Huo L, Zhou H. Pituitary Adenylate CyclaseActivating Polypeptide (PACAP) as a Growth Hormone (GH)-releasing factor in grass carp. I. Functional coupling of cyclic adenosine $3^{\prime}, 5^{\prime}-$ monophosphate and $\mathrm{ca} 2+/$ calmodulin- dependent signaling pathways in PACAP-induced GH secret. Endocrinology (2005) 146:5407-24. doi: 10.1210/en.2005-0294

173. Kong HS, Zhou H, Yang Y, He M, Jiang Y, Wong AOL. Pituitary Adenylate Cyclase-Activating Polypeptide (PACAP) as a Growth Hormone (GH)releasing factor in grass carp: II. Solution structure of a brain-specific PACAP by nuclear magnetic resonance spectroscopy and functional studies on GH release and gene e. Endocrinology (2007) 148:5042-59. doi: 10.1210/en.2007-0576

174. Peeters K, Langouche L, Vandesande F, Darras VM, Berghman LR. Effects of pituitary adenylate cyclase-activating polypeptide (PACAP) on cAMP formation and growth hormone release from chicken anterior pituitary cells. Ann N Y Acad Sci (1998) 865:471-4. doi: 10.1111/j.1749-6632.1998.tb11218.x

175. Tatemoto K, Carlquist M, Mutt V. Neuropeptide Y - A novel brain peptide with structural similarities to peptide YY and pancreatic polypeptide. Nature (1982) 296:659-60. doi: 10.1038/296659a0

176. Gehlert DR. Introduction to the reviews on neuropeptide Y. Neuropeptides (2004) 38:135-40. doi: 10.1016/j.npep.2004.07.002

177. Volkoff H, Canosa LF, Unniappan S, Cerdá-Reverter JM, Bernier NJ, Kelly SP, et al. Neuropeptides and the control of food intake in fish. Gen Comp Endocrinol (2005) 142:3-19. doi: 10.1016/j.ygcen.2004.11.001 
178. Loh K, Herzog H, Shi Y-C. Regulation of energy homeostasis by the NPY system. Trends Endocrinol Metab (2015) 26:125-35. doi: 10.1016/ j.tem.2015.01.003

179. Cerdá-Reverter JM, Larhammar D. Neuropeptide Y family of peptides: Structure, anatomical expression, function, and molecular evolution. Biochem Cell Biol (2000) 78:371-92. doi: 10.1139/o00-004

180. Volkoff $\mathrm{H}$. The neuroendocrine regulation of food intake in fish: A review of current knowledge. Front Neurosci (2016) 10:540. doi: 10.3389/fnins. 2016.00540

181. Li M, Tan X, Sui Y, Jiao S, Wu Z, Wang L, et al. The stimulatory effect of neuropeptide $\mathrm{Y}$ on growth hormone expression, food intake, and growth in olive flounder (Paralichthys olivaceus). Fish Physiol Biochem (2017) 43:11-8. doi: 10.1007/s10695-016-0263-x

182. Peng C, Humphries S, Peter RE, Rivier JE, Blomqvist AG, Larhammar D. Actions of goldfish neuropeptide $\mathrm{Y}$ on the secretion of growth hormone and gonadotropin-II in female goldfish. Gen Comp Endocrinol (1993) 90:306-17. doi: $10.1006 /$ gcen.1993.1086

183. Wu S, Li B, Lin H, Li W. Stimulatory effects of neuropeptide Y on the growth of orange-spotted grouper (Epinephelus coioides). Gen Comp Endocrinol (2012) 179(2):159-66. doi: 10.1016/j.ygcen.2012.08.010

184. Estienne MJ, Barb CR. The control of adenohypophysial hormone secretion by amino acids and peptides in swine. Domest Anim Endocrinol (2005) 29:34-42. doi: 10.1016/j.domaniend.2005.02.020

185. Garcia MR, Amstalden M, Keisler DH, Raver N, Gertler A, Williams GL. Leptin attenuates the acute effects of centrally administered neuropeptide $Y$ on somatotropin but not gonadotropin secretion in ovariectomized cows. Domest Anim Endocrinol (2004) 26:189-200. doi: 10.1016/ j.domaniend.2003.10.003

186. Pierroz DD, Catzeflis C, Aebi AC, Rivier JE, Aubert ML. Chronic administration of neuropeptide $\mathrm{Y}$ into the lateral ventricle inhibits both the pituitary-testicular axis and growth hormone and insulin-like growth factor I secretion in intact adult male rats. Endocrinology (1996) 137:3-12. doi: 10.1210/endo.137.1.8536627

187. Rettori V, Milenkovic L, Aguila MC, McCann SM. Physiologically significant effect of neuropeptide $\mathrm{Y}$ to suppress growth hormone release by stimulating somatostatin discharge. Endocrinology (1990) 126:2296-301. doi: 10.1210/ endo-126-5-2296

188. Baranowska B, Chmielowska M, Radzikowska M, Borowiec M, Roguski K, Wasilewska-Dziubinska E. Effects of neuropeptide Y (NPY), galanin and vasoactive intestinal peptide (VIP) on pituitary hormone release and on ovarian steroidogenesis. Neuroendocrinol Lett (2000) 20:385-9.

189. Bøler J, Enzmann F, Folkers K, Bowers CY, Schally AV. The identity of chemical and hormonal properties of the thyrotropin releasing hormone and pyroglutamyl-histidyl-proline amide. Biochem Biophys Res Commun (1969) 37:705-10. doi: 10.1016/0006-291X(69)90868-7

190. Burgus R, Dunn TF, Desiderio D, Guillemin R. Molecular structure of the hypothalamic hypophysiotropic TRF factor of ovine origin: mass spectrometry demonstration of the PCA-His-Pro-NH2 sequence. Comptes rendus Hebd Des seances l"Academie Des Sci Ser D Sci Nat (1969) 269:1870-3.

191. Labrie F, Barden N, Poirier G, De Lean A. Binding of thyrotropin-releasing hormone to plasma membranes of bovine anterior pituitary gland (hormone receptor-adenylate cyclase-equilibrium constant-( $3 \mathrm{H}$ )thyrotropin). Proc Natl Acad Sci U.S.A. (1972) 69:283-7. doi: 10.1073/pnas.69.1.283

192. Joseph-Bravo P, Jaimes-Hoy L, Uribe RM, Charli JL. TRH, the first hypophysiotropic releasing hormone isolated: Control of the pituitarythyroid axis. J Endocrinol (2015) 226:T85-T100. doi: 10.1530/JOE-15-0124

193. Gracia-Navarro F, Castaño JP, Malagón MM, Torronteras R. Subcellular responsiveness of amphibian growth hormone cells after TSH-releasing hormone stimulation. Gen Comp Endocrinol (1991) 84:94-103. doi: 10.1016/ 0016-6480(91)90068-H

194. Ahene CA, Lea RW, Harvey S. Thyrotrophin-releasing hormone-induced growth hormone $(\mathrm{GH})$ secretion in anaesthetized chickens: Inhibition by GH-releasing factor at central sites. J Endocrinol (1991) 128:13-9. doi: $10.1677 /$ joe. 0.1280013

195. Galas L, Raoult E, Tonon M-C, Okada R, Jenks BG, Castaño JP, et al. TRH acts as a multifunctional hypophysiotropic factor in vertebrates. Gen Comp Endocrinol (2009) 164:40-50. doi: 10.1016/j.ygcen.2009.05.003
196. Deal CK, Volkoff H. The Role of the Thyroid Axis in Fish. Front Endocrinol (Lausanne) (2020) 11:596585. doi: 10.3389/fendo.2020.596585

197. Tata JR. The road to nuclear receptors of thyroid hormone. Biochim Biophys Acta - Gen Subj (2013) 1830:3860-6. doi: 10.1016/j.bbagen.2012.02.017

198. Moeller LC, Cao X, Dumitrescu AM, Seo H, Refetoff S. Thyroid hormone mediated changes in gene expression can be initiated by cytosolic action of the thyroid hormone receptor $\beta$ through the phosphatidylinositol 3-kinase pathway. Nucl Recept Signal (2006) 4:nrs.04020. doi: 10.1621/nrs.04020

199. Melamed P, Eliahu N, Levavi-Sivan B, Ofir M, Farchi-Pisanty O, RentierDelrue F, et al. Hypothalamic and thyroidal regulation of growth hormone in tilapia. Gen Comp Endocrinol (1995) 97:13-30. doi: 10.1006/gcen.1995.1002

200. Moav B, McKeown BA. Thyroid hormone increases transcription of growth hormone mRNA in rainbow trout pituitary. Horm Metab Res (1992) 24:104. doi: $10.1055 / \mathrm{s}-2007-1003242$

201. Dobner PR, Kawasaki ES, Yu LY, Bancroft FC. Thyroid or glucocorticoid hormone induces pre-growth-hormone mRNA and its probable nuclear precursor in rat pituitary cells. Proc Natl Acad Sci USA (1981) 78:2230-4. doi: 10.1073/pnas.78.4.2230

202. Koenig RJ, Brent GA, Warne RL, Larsen PR, Moore DD. Thyroid hormone receptor binds to a site in the rat growth hormone promoter required for induction by thyroid hormone. Proc Natl Acad Sci USA (1987) 84:5670-4. doi: $10.1073 /$ pnas. 84.16 .5670

203. Brent GA, Harney JW, Chen Y, Warne RL, Moore DD, Larsen PR. Mutations of the rat growth hormone promoter which increase and decrease response to thyroid hormone define a consensus thyroid hormone response element. Mol Endocrinol (1989) 3:1996-2004. doi: 10.1210/mend-3-12-1996

204. Glass CK, Franco R, Weinberger C, Albert VR, Evans RM, Rosenfeld MG. A c-erb-A binding site in rat growth hormone gene mediates trans-activation by thyroid hormone. Nature (1987) 329:738-41. doi: 10.1038/329738a0

205. Bargi-Souza P, Goulart-Silva F, Nunes MT. Novel aspects of T3 actions on GH and TSH synthesis and secretion: Physiological implications. $J$ Mol Endocrinol (2017) 59:R167-78. doi: 10.1530/JME-17-0068

206. Giustina A, Wehrenberg WB. Influence of thyroid hormones on the regulation of growth hormone secretion. Eur J Endocrinol (1995) 133:64653. doi: 10.1530/eje.0.1330646

207. Wang Y, Zhang S. Expression and regulation by thyroid hormone (TH) of zebrafish IGF-I gene and amphioxus IGFl gene with implication of the origin of TH/IGF signaling pathway. Comp Biochem Physiol - A Mol Integr Physiol (2011) 160:474-9. doi: 10.1016/j.cbpa.2011.08.005

208. Schmid AC, Lutz I, Kloas W, Reinecke M. Thyroid hormone stimulates hepatic IGF-I mRNA expression in a bony fish, the tilapia Oreochromis mossambicus, in vitro and in vivo. Gen Comp Endocrinol (2003) 130:129-34. doi: 10.1016/S0016-6480(02)00577-4

209. Rodriguez-Arnao J, Miell JP, Ross RJM. Influence of thyroid hormones on the GH-IGF-I axis. Trends Endocrinol Metab (1993) 4:169-73. doi: 10.1016/ 1043-2760(93)90107-P

210. Vale W, Rivier C, Brown MR, Spiess J, Koob G, Swanson L, et al. Chemical and biological characterization of corticotropin releasing factor. Recent Prog Horm Res (1983) 39:245-70. doi: 10.1016/b978-0-12-571139-5.50010-0

211. Lovejoy DA, Balment RJ. Evolution and physiology of the corticotropinreleasing factor (CRF) family of neuropeptides in vertebrates. Gen Comp Endocrinol (1999) 115:1-22. doi: 10.1006/gcen.1999.7298

212. Usui $T$, Nakai $Y$, Tsukada $T$, Jingami $H$, Takahashi H, Fukata J, et al. Expression of adrenocorticotropin-releasing hormone precursor gene in placenta and other nonhypothalamic tissues in man. Mol Endocrinol (1988) 2:871-5. doi: 10.1210/mend-2-9-871

213. Orth DN. Corticotropin-releasing hormone in humans. Endocr Rev (1992) 13:164-91. doi: 10.1210/edrv-13-2-164

214. Grammatopoulos DK. Insights into mechanisms of corticotropin-releasing hormone receptor signal transduction. Br J Pharmacol (2012) 166:85-97. doi: $10.1111 / \mathrm{j} .1476-5381.2011 .01631 . x$

215. Matsuda K. Regulation of feeding behavior and psychomotor activity by corticotropin-releasing hormone (CRH) in fish. Front Neurosci (2013) 7:91:91. doi: 10.3389/fnins.2013.00091

216. De Groef B, Van Der Geyten S, Darras VM, Kühn ER. Role of corticotropinreleasing hormone as a thyrotropin-releasing factor in non-mammalian vertebrates. Gen Comp Endocrinol (2006) 146:62-8. doi: 10.1016/ j.ygcen.2005.10.014 
217. Rousseau K, Dufour S. Comparative aspects of GH and metabolic regulation in lower vertebrates. Neuroendocrinology (2007) 86:165-74. doi: 10.1159/ 000101029

218. Chin SO, Rhee SY, Chon S, Hwang YC, Jeong IK, Oh S, et al. Investigation of responsiveness to thyrotropin-releasing hormone in growth hormoneproducing pituitary adenomas. Int J Endocrinol (2013) 2013:159858. doi: $10.1155 / 2013 / 159858$

219. Joustra SD, Roelfsema F, Van Trotsenburg ASP, Schneider HJ, Kosilek RP, Kroon HM, et al. IGSF1 Deficiency Results in Human and Murine Somatotrope Neurosecretory Hyperfunction. J Clin Endocrinol Metab (2020) 105:70-84. doi: 10.1210/clinem/dgz093

220. Schally AV, Arimura A, Kastin AJ, Matsuo H, Baba Y, Redding TW, et al. Gonadotropin-releasing hormone: One polypeptide regulates secretion of luteinizing and follicle-stimulating hormones. Science (80-) (1971) 173:1036-8. doi: 10.1126/science.173.4001.1036

221. Duan C, Allard J. Gonadotropin-releasing hormone neuron development in vertebrates. Gen Comp Endocrinol (2020) 292:113465. doi: 10.1016/ j.ygcen.2020.113465

222. Cohen-Tannoudji J, Avet C, Garrel G, Counis R, Simon V. Decoding high gonadotropin-releasing hormone pulsatility: A role for GnRH receptor coupling to the cAMP pathway? Front Endocrinol (Lausanne) (2012) 3:107. doi: $10.3389 /$ fendo. 2012.00107

223. Chang JP, Pemberton JG. Comparative aspects of GnRH-Stimulated signal transduction in the vertebrate pituitary - Contributions from teleost model systems. Mol Cell Endocrinol (2018) 463:142-67. doi: 10.1016/ j.mce.2017.06.002

224. Marques P, Skorupskaite K, George JT, Anderson RA. Physiology of GNRH and Gonadotropin Secretion (2000). MDText.com, Inc. Available at: http:// www.ncbi.nlm.nih.gov/pubmed/25905297 (Accessed October 6, 2020).

225. Cook H, Berkenbosch JW, Fernhout MJ, Yu KL, Peter RE, Chang JP, et al. Demonstration of gonadotropin releasing-hormone receptors on gonadotrophs and somatotrophs of the goldfish: an electron microscope study. Regul Pept (1991) 36:369-78. doi: 10.1016/0167-0115(91)90070-W

226. Illing N, Troskie BE, Nahorniak CS, Hapgood JP, Peter RE, Millar RP. Two gonadotropin-releasing hormone receptor subtypes with distinct ligand selectivity and differential distribution in brain and pituitary in the goldfish (Carassius auratus). Proc Natl Acad Sci USA (1999) 96:2526-31. doi: 10.1073/pnas.96.5.2526

227. Ma Y, Ladisa C, Chang JP, Habibi HR. Seasonal related multifactorial control of pituitary gonadotropin and growth hormone in female goldfish: influences of neuropeptides and thyroid hormone. Front Endocrinol (Lausanne) (2020) 11:1-21. doi: 10.3389/fendo.2020.00175

228. Khalid E, Chang JP. $\beta$-Arrestin-dependent signaling in GnRH control of hormone secretion from goldfish gonadotrophs and somatotrophs. Gen Comp Endocrinol (2020) 287:113340. doi: 10.1016/j.ygcen.2019.113340

229. Marchant TA, Marchant TA, Nahorniak CS, Peter RE. Evidence that gonadotropin-releasing hormone also functions as a growth hormonereleasing factor in the goldfish. Endocrinology (1989) 124:2509-18. doi: 10.1210/endo-124-5-2509

230. Chen D, Yang W, Han S, Yang H, Cen X, Liu J, et al. A type IIb, but not type $\mathrm{IIa}, \mathrm{GnRH}$ receptor mediates GnRH-induced release of growth hormone in the Ricefield Eel. Front Endocrinol (Lausanne) (2018) 9:721. doi: 10.3389/ fendo.2018.00721

231. Lescroart O, Roelants I, Mikolajczyk T, Bosma PT, Schulz RW, Kühn ER, et al. A radioimmunoassay for African catfish growth hormone: Validation and effects of substances modulating the release of growth hormone. Gen Comp Endocrinol (1996) 104:147-55. doi: 10.1006/ gcen.1996.0157

232. Bosma PT, Kolk SM, Rebers FEM, Lescroart O, Roelants I, Willems PHGM, et al. Gonadotrophs but not somatotrophs early ganadotrophin-releasing hormone receptors: Receptor localisation, intracellular calcium, and gonadotrophin and GH release. J Endocrinol (1997) 152:437-46. doi: $10.1677 /$ joe. 0.1520437

233. Weil C, Carré F, Blaise O, Breton B, Le Bail PY. Differential effect of insulinlike growth factor I on in vitro gonadotropin (I and II) and growth hormone secretions in rainbow trout (Oncorhynchus mykiss) at different stages of the reproductive cycle. Endocrinology (1999) 140:2054-62. doi: 10.1210/ endo.140.5.6747
234. May PB, Mittler JC, Ertel NH. Enkephalins and Pituitary Hormone Release Modification of Responsiveness to LHRH. Horm Res (1979) 10:57-63. doi: $10.1159 / 000178989$

235. Carel JC. Management of short stature with GnRH agonist and co-treatment with growth hormone: A controversial issue. Mol Cell Endocrinol (2006) 254-255:226-33. doi: 10.1016/j.mce.2006.04.034

236. Erspamer V, Erspamer GF, Inselvini M. Some pharmacological actions of alytesin and bombesin. J Pharm Pharmacol (1970) 22:875-6. doi: 10.1111/ j.2042-7158.1970.tb08465.x

237. Holmgren S, Axelsson M, Jensen J, Aldman G, Sundell K, Jonsson AC. Bombesin-like immunoreactivity and the effect of bombesin in the gut, circulatory system and lung of the caiman, Caiman crocodylus crocodylus, and the crocodile, Crocodylus porosus. Exp Biol (1989) 48:261-71.

238. Erspamer V. Discovery, isolation, and characterization of Bombesin-like peptides. Ann N Y Acad Sci (1988) 547:3-9. doi: 10.1111/j.17496632.1988.tb23870.x

239. Merali Z, Graitson S, MacKay JC, Kent P. Stress and eating: A dual role for bombesin-like peptides. Front Neurosci (2013) 7:193. doi: 10.3389/ fnins.2013.00193

240. Bjenning C, Jönsson AC, Holmgren S. Bombesin-like immunoreactive material in the gut, and the effect of bombesin on the stomach circulatory system of an elasmobranch fish, Squalus acanthias. Regul Pept (1990) 28:5769. doi: 10.1016/0167-0115(90)90064-4

241. Himick BA, Peter RE. Bombesin-like immunoreactivity in the forebrain and pituitary and regulation of anterior pituitary hormone release by bombesin in goldfish. Neuroendocrinology (1995) 61:365-76. doi: 10.1159/ 000126858

242. Jensen RT, Battey JF, Spindel ER, Benya RV. International union of pharmacology. LXVIII. Mammalian bombesin receptors: Nomenclature, distribution, pharmacology, signaling, and functions in normal and disease states. Pharmacol Rev (2008) 60:1-42. doi: 10.1124/pr.107.07108

243. Rivier C, Rivier J, Vale W. The effect of bombesin and related peptides on prolactin and growth hormone secretion in the rat. Endocrinology (1978) 102:519-22. doi: 10.1210/endo-102-2-519

244. Westendorf JM, Schonbrunn A. Bombesin stimulates prolactin and growth hormone release by pituitary cells in culture. Endocrinology (1982) 110:3528. doi: 10.1210/endo-110-2-352

245. Murphy WA, Lance VA, Heiman ML, Hocart SJ, Coy DH. Prolonged inhibition of growth hormone secretion by peripheral injection of bombesin is mediated by somatostatin in the rat. Endocrinology (1985) 117:1179-83. doi: 10.1210/endo-117-3-1179

246. Benitez L, Mallo F, Alvarez CV, Burguera B, Sanchez-Franco F, Dieguez C. Estrogen-dependent effects of bombesin on in vivo growth hormone secretion in the rat. Neuroendocrinology (1990) 52:608-11. doi: 10.1159/000125652

247. Kojima M, Hosoda H, Date Y, Nakazato M, Matsuo H, Kangawa K. Ghrelin is a growth-hormone-releasing acylated peptide from stomach. Nature (1999) 402:656-60. doi: 10.1038/45230

248. Howard AD, Feighner SD, Cully DF, Arena JP, Liberator PA, Rosenblum CI, et al. A receptor in pituitary and hypothalamus that functions in growth hormone release. Science (80-) (1996) 273:974-7. doi: 10.1126/ science.273.5277.974

249. Mohan H, Unniappan S. Discovery of ghrelin O-acyltransferase. Endocr Dev (2013) 25:16-24. doi: 10.1159/000346039

250. Date Y, Murakami N, Kojima M, Kuroiwa T, Matsukura S, Kangawa K, et al. Central effects of a novel acylated peptide, ghrelin, on growth hormone release in rats. Biochem Biophys Res Commun (2000) 275:477-80. doi: $10.1006 /$ bbrc.2000.3342

251. Seoane LM, Tovar S, Baldelli R, Arvat E, Ghigo E, Casanueva FF, et al. Ghrelin elicits a marked stimulatory effect on GH secretion in freelymoving rats. Eur J Endocrinol (2000) 143(5):R7-9. doi: 10.1530/eje.0. 143R007

252. Arvat E, Di Vito L, Broglio F, Papotti M, Muccioli G, Dieguez C, et al. Preliminary evidence that Ghrelin, the natural GH secretagogue (GHS)receptor ligand, strongly stimulates GH secretion in humans. J Endocrinol Invest (2000) 23:493-5. doi: 10.1007/BF03343763

253. Takaya K, Ariyasu H, Kanamoto N, Iwakura H, Yoshimoto A, Harada M, et al. Ghrelin strongly stimulates growth hormone (GH) release in humans. J Clin Endocrinol Metab (2000) 85:4908-11. doi: 10.1210/jcem.85.12.7167 
254. Ahmed S, Harvey S. Ghrelin: A hypothalamic GH-releasing factor in domestic fowl (Gallus domesticus). J Endocrinol (2002) 172:117-25. doi: 10.1677 /joe.0.1720117

255. Shepherd BS, Johnson JK, Silverstein JT, Parhar IS, Vijayan MM, McGuire A, et al. Endocrine and orexigenic actions of growth hormone secretagogues in rainbow trout (Oncorhynchus mykiss). Comp Biochem Physiol - A Mol Integr Physiol (2007) 146:390-9. doi: 10.1016/j.cbpa.2006.11.004

256. Unniappan S, Peter RE. In vitro and in vivo effects of ghrelin on luteinizing hormone and growth hormone release in goldfish. Am J Physiol - Regul Integr Comp Physiol (2004) 286:1093-101. doi: 10.1152/ajpregu.00669.2003

257. Ogawa S, Liu X, Shepherd BS, Parhar IS. Ghrelin stimulates growth hormone release from the pituitary via hypothalamic growth hormone-releasing hormone neurons in the cichlid, Oreochromis niloticus. Cell Tissue Res (2018) 374:349-65. doi: 10.1007/s00441-018-2870-6

258. Grey CL, Chang JP. Ghrelin-induced growth hormone release from goldfish pituitary cells is nitric oxide dependent. Gen Comp Endocrinol (2012) 179:152-8. doi: 10.1016/j.ygcen.2012.08.012

259. Grey CL, Chang JP. Differential involvement of protein kinase $\mathrm{C}$ and protein kinase A in ghrelin-induced growth hormone and gonadotrophin release from goldfish (Carassius auratus) pituitary cells. J Neuroendocrinol (2011) 23:1273-87. doi: 10.1111/j.1365-2826.2011.02221.x

260. Picha ME, Strom CN, Riley LG, Walker AA, Won ET, Johnstone WM, et al. Plasma ghrelin and growth hormone regulation in response to metabolic state in hybrid striped bass: Effects of feeding, ghrelin and insulin-like growth factor-I on in vivo and in vitro GH secretion. Gen Comp Endocrinol (2009) 161:365-72. doi: 10.1016/j.ygcen.2009.01.026

261. Gauna C, van de Zande B, van Kerkwijk A, Themmen APN, van der Lely AJ, Delhanty PJD. Unacylated ghrelin is not a functional antagonist but a full agonist of the type la growth hormone secretagogue receptor (GHS-R). Mol Cell Endocrinol (2007) 274:30-4. doi: 10.1016/j.mce.2007.05.010

262. Malagón MM, Luque RM, Ruiz-Guerrero E, Rodríguez-Pacheco F, GarcíaNavarro S, Casanueva FF, et al. Intracellular signaling mechanisms mediating ghrelin-stimulated growth hormone release in somatotropes. Endocrinology (2003) 144:5372-80. doi: 10.1210/en.2003-0723

263. Blanco AM, Bertucci JI, Unniappan S. FGF21 mimics a fasting-induced metabolic state and increases appetite in zebrafish. Sci Rep (2020) 10:6993. doi: 10.1038/s41598-020-63726-W

264. Aguilar E, Tena-Sempere M, Pinilla L. Role of excitatory amino acids in the control of growth hormone secretion. Endocrine (2005) 28:295-301. doi: 10.1385/ENDO:28:3:295

265. Tena-Sempere M, Pinilla L, González LC, Aguilar E. Regulation of growth hormone $(\mathrm{GH})$ secretion by different glutamate receptor subtypes in the rat. Amino Acids (2000) 18:1-16. doi: 10.1007/s007260050001

266. Ghigo E, Arvat E, Bellone J, Ramunni J, Camanni F. Neurotransmitter control of growth hormone secretion in humans. J Pediatr Endocrinol Metab (1993) 6:263-6. doi: 10.1515/JPEM.1993.6.3-4.263

267. Cuttler L, Collins BJ, Marone PA, Szabo M. The effect of isobutylmethylxanthine, forskolin, and cholera toxin on growth hormone release from pituitary cell cultures of perinatal and mature rats. Endocr Res (1993) 19:33-46. doi: 10.3109/ 07435809309035406

268. Garrel G, Simon V, Thieulant ML, Cayla X, Garcia A, Counis R, et al. Sustained gonadotropin-releasing hormone stimulation mobilizes the cAMP/PKA pathway to induce nitric oxide synthase type 1 expression in rat pituitary cells in vitro and in vivo at proestrus. Biol Reprod (2010) 82:1170-9. doi: 10.1095/biolreprod.109.082925

269. Formosa R, Xuereb-Anastasi A, Vassallo J. Aip regulates cAMP signalling and GH secretion in GH3 cells. Endocr Relat Cancer (2013) 20:495-505. doi: 10.1530/ERC-13-0043

270. Kineman RD, Kamegai J, Frohman LA. Growth hormone (GH)-releasing hormone (GHRH) and the GH secretagogue (GHS), L692,585, differentially modulate rat pituitary GHS receptor and GHRH receptor messenger ribonucleic acid levels. Endocrinology (1999) 140:3581-6. doi: 10.1210/endo.140.8.6918

271. Bilezikjian LM, Vale WW. Stimulation of adenosine $3^{\prime}, 5^{\prime}$-monophosphate production by growth hormone-releasing factor and its inhibition by somatostatin in anterior pituitary cells in vitro. Endocrinology (1983) 113:1726-31. doi: 10.1210/endo-113-5-1726

272. Sandberg M, Butt E, Nolte C, Fischer L, Halbrugge M, Beltman J, et al. Characterization of Sp-5,6-dichloro-1- $\beta$-D-ribofuranosyl-benzimidazole- $3^{\prime}, 5^{\prime}-$ monophosphorothioate (Sp-5,6-DCl-cBiMPS) as a potent and specific activator of cyclic-AMP-dependent protein kinase in cell extracts and intact cells. Biochem J (1991) 279:521-7. doi: 10.1042/bj2790521

273. Wang LF, Piguet AC, Schmidt K, Tordjmann T, Dufour JF. Activation of CREB by tauroursodeoxycholic acid protects cholangiocytes from apoptosis induced by mTOR inhibition. Hepatology (2005) 41:1241-51. doi: 10.1002/ hep. 20697

274. Johnson JD, Chang JP. Novel, thapsigargin-insensitive intracellular Ca2+ stores control growth hormone release from goldfish pituitary cells. Mol Cell Endocrinol (2000) 165:139-50. doi: 10.1016/S0303-7207(00)00252-5

275. Johnson JD, Chang JP. Agonist-specific and sexual stage-dependent inhibition of gonadotropin-releasing hormone-stimulated gonadotropin and growth hormone release by ryanodine: Relationship to sexual stagedependent caffeine-sensitive hormone release. J Neuroendocrinol (2002) 14:144-55. doi: 10.1046/j.0007-1331.2001.00756.x

276. Dai Y, Wang S, Tominaga M, Yamamoto S, Fukuoka T, Higashi T, et al. Sensitization of TRPA1 by PAR2 contributes to the sensation of inflammatory pain. J Clin Invest (2007) 117:1979-87. doi: 10.1172/JCI30951

277. Pérez-Sánchez J. The involvement of growth hormone in growth regulation, energy homeostasis and immune function in the gilthead sea bream ( Sparus aurata ): a short review. Fish Physiol Biochem (2000) 22:135-44. doi: 10.1023/ A:1007816015345

278. Yunker WK, Chang JP. Somatostatin actions on a protein kinase Cdependent growth hormone secretagogue cascade. Mol Cell Endocrinol (2001) 175:193-204. doi: 10.1016/S0303-7207(01)00386-0

279. Noh MY, Kim YS, Lee KY, Lee YJ, Kim SH, Yu HJ, et al. The early activation of PI3K strongly enhances the resistance of cortical neurons to hypoxic injury via the activation of downstream targets of the PI3K pathway and the normalization of the levels of PARP activity, ATP, and NAD+. Mol Neurobiol (2013) 47:757-69. doi: 10.1007/s12035-012-8382-6

280. Mohi MG, Arai KI, Watanabe S. Activation and functional analysis of Janus kinase 2 in BA/F3 cells using the coumermycin/gyrase B system. Mol Biol Cell (1998) 9:3299-308. doi: 10.1091/mbc.9.12.3299

281. Wikiera B, Zawadzka K, Łaczmański, Słoka N, Bolanowski M, Basiak A, et al. Growth hormone treatment increases plasma irisin concentration in patients with Turner syndrome. Horm Metab Res (2017) 49:122-8. doi: 10.1055/s0042-119788

282. Leung AKW, Ramesh N, Vogel C, Unniappan S. Nucleobindins and encoded peptides: From cell signaling to physiology. Adv Protein Chem Struct Biol (2019) 116:91-133. doi: 10.1016/bs.apcsb.2019.02.001

283. Hohenegger M, Waldhoer M, Beindl W, Böing B, Kreimeyer A, Nickel P, et al. Gs $\alpha$-selective G protein antagonists. Proc Natl Acad Sci USA (1998) 95:346-51. doi: 10.1073/pnas.95.1.346

284. Orth JHC, Fester I, Preuss I, Agnoletto L, Wilson BA, Aktories K. Activation of Goi and subsequent uncoupling of receptor-Goi signaling by Pasteurella multocida toxin. J Biol Chem (2008) 283:23288-94. doi: 10.1074/ jbc.M803435200

285. Omar F, Findlay JE, Carfray G, Allcock RW, Jiang Z, Moore C, et al. Smallmolecule allosteric activators of PDE4 long form cyclic AMP phosphodiesterases. Proc Natl Acad Sci USA (2019) 116:13320-9. doi: 10.1073/pnas.1822113116

286. Peltier J, O'Neill A, Schaffer DV. PI3K/Akt and CREB regulate adult neural hippocampal progenitor proliferation and differentiation. Dev Neurobiol (2007) 67:1348-61. doi: 10.1002/dneu.20506

287. Kang S, Dahl R, Hsieh W, Shin A, Zsebo KM, Buettner C, et al. Small molecular allosteric activator of the sarco/endoplasmic reticulum $\mathrm{Ca} 2+-$ ATPase (SERCA) attenuates diabetes and metabolic disorders. J Biol Chem (2016) 291:5185-98. doi: 10.1074/jbc.M115.705012

Conflict of Interest: The authors declare that the research was conducted in the absence of any commercial or financial relationships that could be construed as a potential conflict of interest.

Copyright (๑) 2021 Vélez and Unniappan. This is an open-access article distributed under the terms of the Creative Commons Attribution License (CC BY). The use, distribution or reproduction in other forums is permitted, provided the original author(s) and the copyright owner(s) are credited and that the original publication in this journal is cited, in accordance with accepted academic practice. No use, distribution or reproduction is permitted which does not comply with these terms. 